Keywords: Tank Closure Grout

High Level Waste Tank

Retention: Permanent

\title{
Tank 18 and 19-F \\ Tier 1A Equipment Fill Mock Up Test Summary
}

David B. Stefanko

Christine A. Langton

September 2011

Savannah River National Laboratory

Savannah River Nuclear Solutions, LLC Aiken, SC 29808

Prepared for the U.S. Department of Energy under contract number DE-AC09-08SR22470.

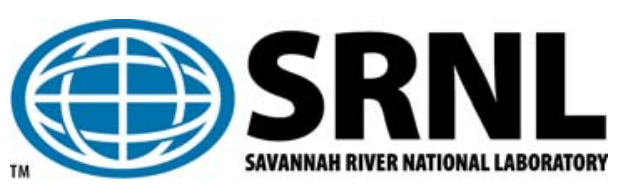




\section{DISCLAIMER}

This work was prepared under an agreement with and funded by the U.S. Government. Neither the U.S. Government or its employees, nor any of its contractors, subcontractors or their employees, makes any express or implied:

1. warranty or assumes any legal liability for the accuracy, completeness, or for the use or results of such use of any information, product, or process disclosed; or

2. representation that such use or results of such use would not infringe privately owned rights; or

3. endorsement or recommendation of any specifically identified commercial product, process, or service.

Any views and opinions of authors expressed in this work do not necessarily state or reflect those of the United States Government, or its contractors, or subcontractors.

\section{Printed in the United States of America}

Prepared for

U.S. Department of Energy 


\section{REVIEWS AND APPROVALS}

AUTHORS:

D. B. Stefanko, E\&CPT Research Programs

Date

C. A. Langton, E\&CPT Research Programs

Date

TECHNICAL REVIEW:

M. G. Serrato, E\&CPT Research Programs / SRNL

Date

APPROVAL:

H. H. Burns, E\&CPT Research Programs, Project Manager

Date

F. M. Pennebaker, E\&CPT Research Programs, Manager

Date

S. L. Marra, E\&CPT Research Programs, Manager

Date

R. Jolly, Jr., FY11 Closure Project Engineering, SRR, Manager

Date

P. E. Carroll, FY12 Closure Project Engineering, SRR, Manager

Date

J. E. Herbert, Waste Removal and Tank Closure, SRR Project Operations, Manager Date 


\section{ACKNOWLEDGEMENTS}

The Tier 1A equipment fill mock up tests described in this report were funded by SRR Project Engineering and SRR Project Operations to support removing Tanks 18 and 19 from FTF service and stabilizing the waste tanks with grout.

Support and technical expertise from the following organizations were much appreciated and essential to this effort. URS Washington Group, Quality and Testing Division, provided technical expertise, testing, and use of the SRS Civil Engineering Laboratory for conducting this study. The SRNL Engineering Development Lab performed calorimeter testing and thermal property measurements which was essential for the grout development. SRR Project Engineering, SRR Project Operations and SRR Construction provided the mock up forms and test plan. They also provided much appreciated project review and support for this effort. 


\section{EXECUTIVE SUMMARY}

The United States Department of Energy (US DOE) has determined that Tanks 18-F and 19-F have met the F-Tank Farm (FTF) General Closure Plan Requirements and are ready to be permanently removed from service [1]. The high-level waste (HLW) tanks have been isolated from FTF facilities. To complete closure they will be filled with grout for the purpose of: 1) physically stabilizing the tanks, 2) limiting / eliminating vertical pathways to residual waste, 3) discouraging future intrusion, and 4) providing an alkaline, chemical reducing environment within the closure boundary to control speciation and solubility of select radionuclides.

Bulk waste removal and heel removal equipment remain in Tanks 18-F and 19-F. This equipment includes the Advance Design Mixer Pump (ADMP), transfer pumps, transfer jets, standard slurry mixer pumps, equipment support masts, sampling masts, dip tube assemblies and robotic crawlers. The present Tank 18 and 19-F closure strategy is to grout the equipment in place and eliminate vertical pathways by filling voids in the equipment to vertical fast pathways and water infiltration [2].

This report documents the results of equipment fill mock up testing authorized under a Technical Task Request (TTR), HLE-TTR-2011-008 [4]. A test plan was prepared for this work [3]. The mock-up tests described in this report were intended to address placement issues identified for grouting the equipment that will be left in Tank 18-F and Tank 19-F.

The specific objectives of the Tier 1A equipment grout mock-up testing include the following:

- Identify the most limiting equipment configurations with respect to internal void space filling

- Specifying and constructing initial test geometries and forms that represent scaled boundary conditions

- Quantify grout properties for minimizing voids and vertical fast paths through the grout to the residual material on the tank floor.

- Identify a target grout rheology for evaluation in the Tier 1A scaled mock-up configurations

- Scale-up production of a grout mix with the target rheology (16 second flow cone value) from 0.25 cubic feet to 4.3 cubic feet. (Ten 0.43 cubic batches were produced because full-scale equipment was not available for the Tier 1A test.)

- Demonstrate continuous gravity filling of the ADMP mock up test form fabricated by SRR

- Demonstrate continuous gravity filling of 1 inch and 2 inch schedule 40 pipe

- Demonstrate filling of 1 inch and 2 inch schedule 40 pipe from the bottom up by discharging through a tube inserted into the pipes.

- Document equipment fill grout data and recommendations

Water testing was added to the SRR Tier 1A mock up test plan to get an indication of the maximum fill rate using a fluid that could be easily removed from the form.

The Tier 1A mock-up test was focused on filling the ADMP and pipes one inch and larger in diameter because these configurations represent and bound the majority of the equipment that will be left in the tanks. The ADMP which is located in center riser of Tank 18-F is a concern because the column for this long-shaft (55 ft) pump is unique and modification to the pump prior to placing it in service limited the flow path options for filling by creating a single flow path for filling and venting the ADMP support column. The large size, vertical orientation, and complicated flow path in the ADMP warrants a detailed description of this piece of ancillary equipment.

A diluted cooling coil grout formulation containing $62.5 \mathrm{wt} \%$ Class F fly ash replacement of the Masterflow 816 grout in the SRR cooling coil mix (Masterflow 816 plus slag) was selected for the Tier 1A mock up test. A more dilute variation of this grout was also included in the Tier 1A mock up test (same 
ingredients but slightly different proportions, i.e., 8 wt. \% more Class F fly ash) because at the time of the Tier 1A mock up test, SRNL personnel still had concerns about amount of heat generated in the selected mix. These mixes were very similar and were blended together for the pipe filling test. Details of the laboratory testing performed on the cooling coil grout and diluted cooling coil grouts are presented in another report [10].

The first five batches used in the Tier 1A mock up test had $62.5 \mathrm{wt} \%$ substitution (replacement) of the Masterflow 816 in the cooling coil grout replaced with Class F fly ash. In batches 6 to 10, Class F fly ash was used to replace $75 \mathrm{wt}$. \% of the Masterflow product in the cooling coil grout formulation. Each batch was mixed with a paddle mixer for three minutes and then sheared in a Ross high shear mixer for 30 seconds. The target ASTM flow cone (rheology) value was 16 seconds (twice that of water). All of the batches were prepared prior to filling the ADMP Tier 1A mock up form.

The Tier 1A mock up form was designed to represent half of the chambers / compartments in the ADMP. The volume ratios of the chambers were representative of the ADMP. The openings in the chamber dividers were the same as in the ADMP. The Tier $1 \mathrm{~A}$ form was gravity filled through a funnel with a $1 / 2$ inch discharge. Two water fill rates were tested. The fill rates were controlled by maintaining either a 9 or 14.5 inch water head height in the funnel. One grout fill rate (9 inch grout head) was tested based on the results of the water test.

The fill times for the ADMP mock up form chambers were recorded for both the water and grout tests. These results plus visual observations indicate that:

- For gravity filling through a funnel or hopper, the fill rate can be controlled by maintaining a grout/liquid constant level in the funnel.

- For the ADMP configuration, the fill rate needs to be low enough to allow venting and to prevent build up of pressure in the lower chambers.

- Based on the Tier 1A mock up test, the ADMP fill rate should be no greater than 4 gallons per minute to allow venting and pressure release. (The fill rate may be refined (probably lowered) by the next series of mock up tests.)

- Assuming the volume of the ADMP column is 673 gallons (3.3 cubic yards) [8], 2.9 hours will be required to fill the ADMP.

- The production scenario / strategy for making grout to fill the ADMP should be based on the maximum fill rate of no more than 4 gallons per minute and the dynamic working time which needs to be confirmed.

- The momentum of the flowing grout keeps the chamber openings from bridging. However, if for some reason the pour is interrupted, restart could still be effective in filling the remaining void volume. For the best chance of maximizing the amount of grout in the ADMP, it should be filled in a single pour based on observations. Testing specifically designed to address the feasibility and consequences of multiple lifts in the ADMP should be considered if subsequent testing performed.

- The modified cooling coil grout mix (2 levels of fly ash dilution) used to fill the ADMP Tier 1A mock up (flow cone rheologies of 16 to 19 seconds) were acceptable for filling the 4 foot mock up.

- Based on flow patterns in the Tier 1A test form, observed chamber flooding, and venting issues, the target rheology (ASTM C939 flow cone value) selected for grout to fill the actual 55 foot high ADMP should be no more than 16 seconds. Equipment fill grout with less than 16 seconds per ASTM C939 is desirable if it can be achieved / produced under field conditions.

Grouting 1 and 2 inch pipes from the top (gravity flow from funnel) and bottom (pumped through a tube inserted to the bottom of the pipe) was easily accomplished for the $5 \mathrm{ft}$ vertical mock up sections. The modified cooling coil grout formulation ( 62.5 to $75 \mathrm{wt} \%$ fly ash replacement) appeared to completely fill the four pipe sections tested. (The pipes need to be cut to confirm this conclusion.) 


\section{TABLE OF CONTENTS}

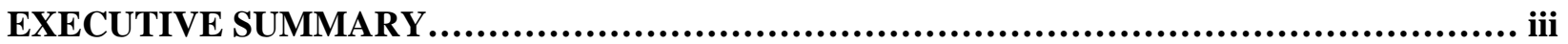

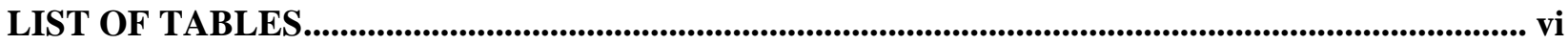

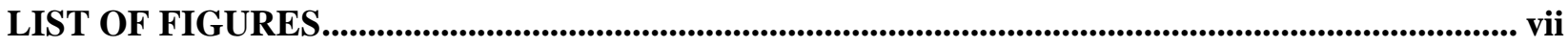

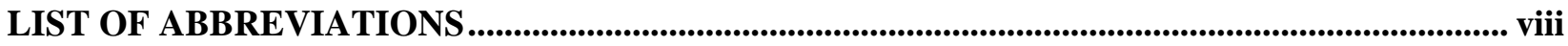

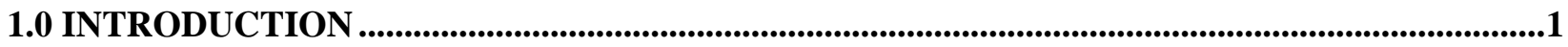

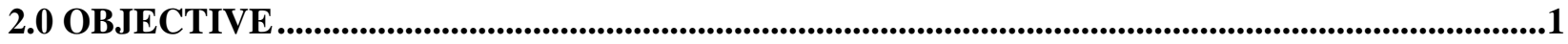

3.0 BACKGROUND..................................................................................................................2

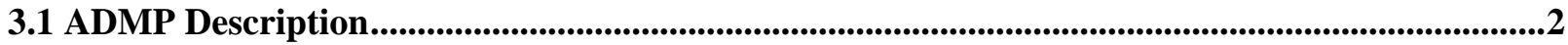

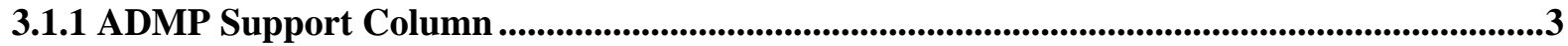

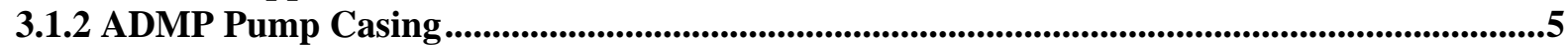

3.1.3 ADMP Rotor ..................................................................................................................7

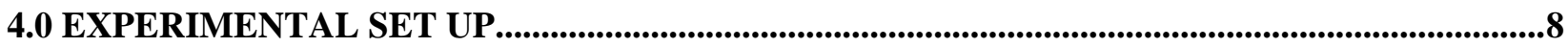

4.1 Test Location ........................................................................................................................8

4.2 Test Forms

4.2.1 ADMP Tier 1A Mock Up..............................................................................................8

4.2.2 Pipe Mock Ups....................................................................................................................9

4.3 Equipment Grout ...........................................................................................................................10

4.3.1 Base Case Cooling Coil Grout.......................................................................................10

4.3.2 Fly Ash Adjusted Cooling Coil Grout for Mock up Test........................................................10

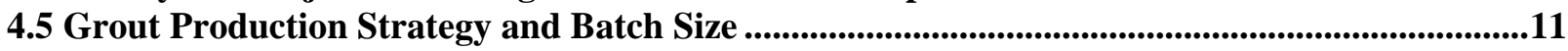

4.6 Method of Mixing........................................................................................................................11

4.7 Fresh and Cured Property Measurements ...............................................................................12

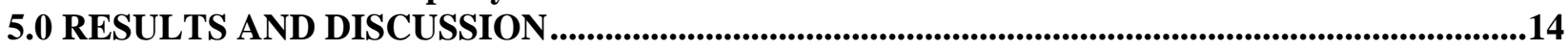

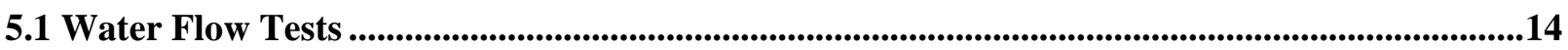

5.2 ADMP Mock Up Form Grout Flow Testing.............................................................................15

5.3 Pipe Fill Mock Up Tests .......................................................................................................17

5.4 Characterization of Grout Used in Tier 1A Mock Up Tests ............................................18

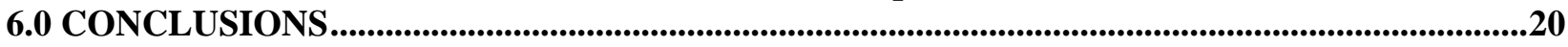

7.0 RECOMMENDATIONS ......................................................................................................21

8.0 REFERENCES .....................................................................................................................22

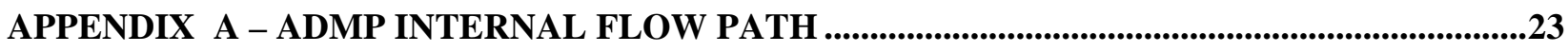

APPENDIX B - ADMP EXTERNAL COLUMN PIPING ...............................................................24

APPENDIX C - Approximate Internal Volumes of Equipment Left in Tanks 18-F and 19-F ..........25 


\section{LIST OF TABLES}

Table 4-1. Tier 1A Grout Formulations (by mass fraction) ................................................................10

Table 4-2. Fresh and Cured Property Tests...................................................................................................12

Table 5-1. ADMP Mock Up form water flow test for $1 / 2$ inch discharge opening SRR Funnel............15

Table 5-2. Grout fill times for chambers in the Tier 1A ADMP test form using a funnel with a $1 / 2$ inch ID spout opening to fill the form.............................................................................17

Table 5-3. Characterization of grouts used in the Tier 1A mock up test. ...............................................18

Table C-1. Tank 18-F Ancillary Equipment Estimated Internal Volumes. ...................................25

Table C-2. Tank 19-F Ancillary Equipment Estimated Internal Volumes.........................................25 


\section{LIST OF FIGURES}

Figure 3-1. Advance Design Mixer Pump 2

Figure 3-2. ADMP Upper and Lower Column Assemblies showing shafts, bearing arrangements, pressure protection device, motor stand, gas seals and pump.

Figure 3-3. Lower ADMP Support Column (motor side) showing 1.0 inch opening restriction at thrust bearing location.

Figure 3-4. ADMP pump casing showing a nozzle, pump inlet screen, sparger ring and water supply piping ............................................................................................................................................5

Figure 3-5. ADMP Impeller.

Figure 3-6. ADMP Sparger (or mining ring) shown spraying process water through 2 of 4 nozzles..

Figure 3-7. ADMP suction screen opening modification (post Tank 18-F installation)..........................7

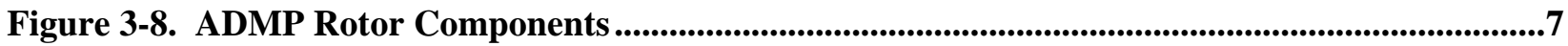

Figure 4-1. ADMP Mock Up form (a) and Funnels for Gravity Filling ADMP Mock Up (b and c)...9

Figure 4-2. Mock up for grouting 1 inch and 2 inch pipes by gravity and pumping. ............................9

Figure 4-3. Calorimeter Temperatures for Coiling Coil Grout for MF816-1H....................................10

Figure 4-4. Preparation of Mix Ingredients ....................................................................................................11

Figure 4-5. Paddle mixing (a and b) and colloidal (shear) mixing (c)...............................................11

Figure 4-6. ASTM C939 flow cone (a) and modified D6103 Static flow test (b).................................13

Figure 4-7. ASTM C231/C231M apparatus for determining air content (a), Compression tester (b) and hydraulic conductivity cell (c).............................................................................13

Figure 5-1. ADMP mock up form (a), Water run (b and c).................................................................14

Figure 5-2. Tier 1A Test form being filled with Grout..................................................................................16

Figure 5-3. Pump filling through tube from bottom up of 2 inch pipe (left) and gravity filling through a funnel of 1 inch pipe (right)....................................................................................17

Figure 5-4. Velocity Variation with Time through Grout...............................................................19

Figure A-1. ADMP internal flow paths..................................................24

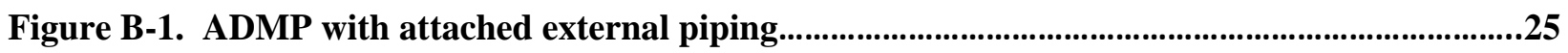




\section{LIST OF ABBREVIATIONS}

\begin{tabular}{ll} 
ADMP & Advanced Design Mixer Pump \\
ASTM & American Society of Testing and Materials \\
DOE & US Department of Energy \\
EEC & Environmental Evaluation Checklist \\
FTF & F-Area Tank Farm \\
HLW & High Level Waste \\
NM & Not measured \\
PA & Performance Assessment \\
QC & Quality Control \\
SEFA & South Eastern Fly Ash \\
SRNL & Savannah River National Laboratory \\
SRNS & Savannah River Nuclear Solutions, LLC \\
SRR & Savannah River Remediations, LLC \\
TBD & To be determined \\
TTQAP & Task Technical and Task Quality Assurance Plan \\
TTR & Technical Task Request \\
UPV & Ultrasonic Pulse Velocity \\
& \\
cu ft & cubic ft \\
lb & pound \\
psig & pounds per square inch (gauge) \\
vol.\% & volume percent \\
w/cm & water to total cementitious \\
& \\
\hline &
\end{tabular}




\subsection{INTRODUCTION}

The United States Department of Energy (US DOE) has determined that Tanks 18-F and 19-F have met the F-Tank Farm (FTF) General Closure Plan Requirements and are ready to be permanently closed [1]. The high-level waste (HLW) tanks have been isolated from FTF facilities. To complete operational closure they will be filled with grout for the purpose of: 1) physically stabilizing the tanks, 2) limiting / eliminating vertical pathways to residual waste, 3 ) discouraging future intrusion, and 4) providing an alkaline, chemical reducing environment within the closure boundary to control speciation and solubility of select radionuclides.

Bulk waste removal and heel removal equipment remain in Tanks 18-F and 19-F. This equipment includes the Advance Design Mixer Pump (ADMP), transfer pumps, transfer jets, standard slurry mixer pumps, equipment-support masts, sampling masts, dip tube assemblies and robotic crawlers. The present Tank 18 and 19-F closure strategy is to grout the equipment in place and eliminate vertical pathways by filling voids in the equipment to vertical fast pathways and water infiltration [2].

This report documents the results of testing identified in the Savannah River Remediation (SRR) Tier 1A Equipment Grout Mockup Test Plan [3]. The work was authorized under a Technical Task Request (TTR), HLE-TTR-2011-008 [4], and was performed according to Task Technical and Quality Assurance Plan (TTQAP), SRNL-RP-2011-00587 [5].

\subsection{OBJECTIVE}

The mock-up tests described in this report were intended to address placement issues identified for grouting the equipment that will be left in Tank 18-F and Tank 19-F. The Tank 18-F and 19-F closure strategy document states that one of the Performance Assessment (PA) requirements for a closed tank is that equipment remaining in the tank be filled to the extent practical and that vertical flow paths 1 inch and larger be grouted [2].

The specific objectives of the Tier 1A equipment grout mock-up testing include:

- Identifying the most limiting equipment configurations with respect to internal void space filling

- Specifying and constructing initial test geometries and forms that represent scaled boundary conditions

- Identifying a target grout rheology for evaluation in the scaled mock-up configurations

- Scaling-up production of a grout mix with the target rheology (16 second flow cone value) from 0.25 cubic feet to 4.3 cubic feet. (Ten 0.43 cubic batches were produced because full-scale equipment was not available for the Tier 1A test.)

- Demonstrating continuous gravity filling of the ADMP mock up test form

- Demonstrating continuous gravity filling of 1 inch and 2 inch schedule 40 pipe

- Demonstrating filling of 1 inch and 2 inch schedule 40 pipe from the bottom up by discharging through a tube inserted into the pipes

The Tier 1A mock-up test focused on the ADMP and pipes at least one inch in diameter. The ADMP which is located in center riser of Tank $18-\mathrm{F}$ is a concern because the column for this long-shaft ( $55 \mathrm{ft}$ ) pump is unique and modification to the pump prior to placing it in service limited the flow path options for filling by creating a single flow path for filling and venting the ADMP support column. The large size, vertical orientation, and complicated flow path in the ADMP warrants a detailed description of this piece of ancillary equipment. 


\subsection{BACKGROUND}

\subsection{ADMP Description}

The ADMP is a long-shaft, vertical, jet mixer pump by Lawrence Pumps, Inc. It operated in Tank 18-F for waste removal from October 2002 to August 2003. The ADMP is about 55 foot long and has a gas filled support column with anti-friction bearings that operated at a minimum column pressure of 75 psig. In the event that the column pressure dropped below $75 \mathrm{psig}$, the pump automatically shut down and an emergency back up supply of nitrogen/conditioned air was fed to the skirt at the bottom of the pump. This protected the mechanical seals from damage and mitigated the risk of contamination entering the support column.

The ADMP is shown in Figure 3-1. The primary components consist of the pump casing, support column, rotor (inside the support column), gas seals (one mounted at the top column and one mounted beneath the radial bearing of the lowest column section), motor stand, motor, turntable and suction screen. Attached to the support column were four (4) pipes that ran from the pump casing (at the bottom) to the motor stand (at the top). These pipes consist of the barrier gas supply, sparger water supply, and two conduits for installing conductivity probes.
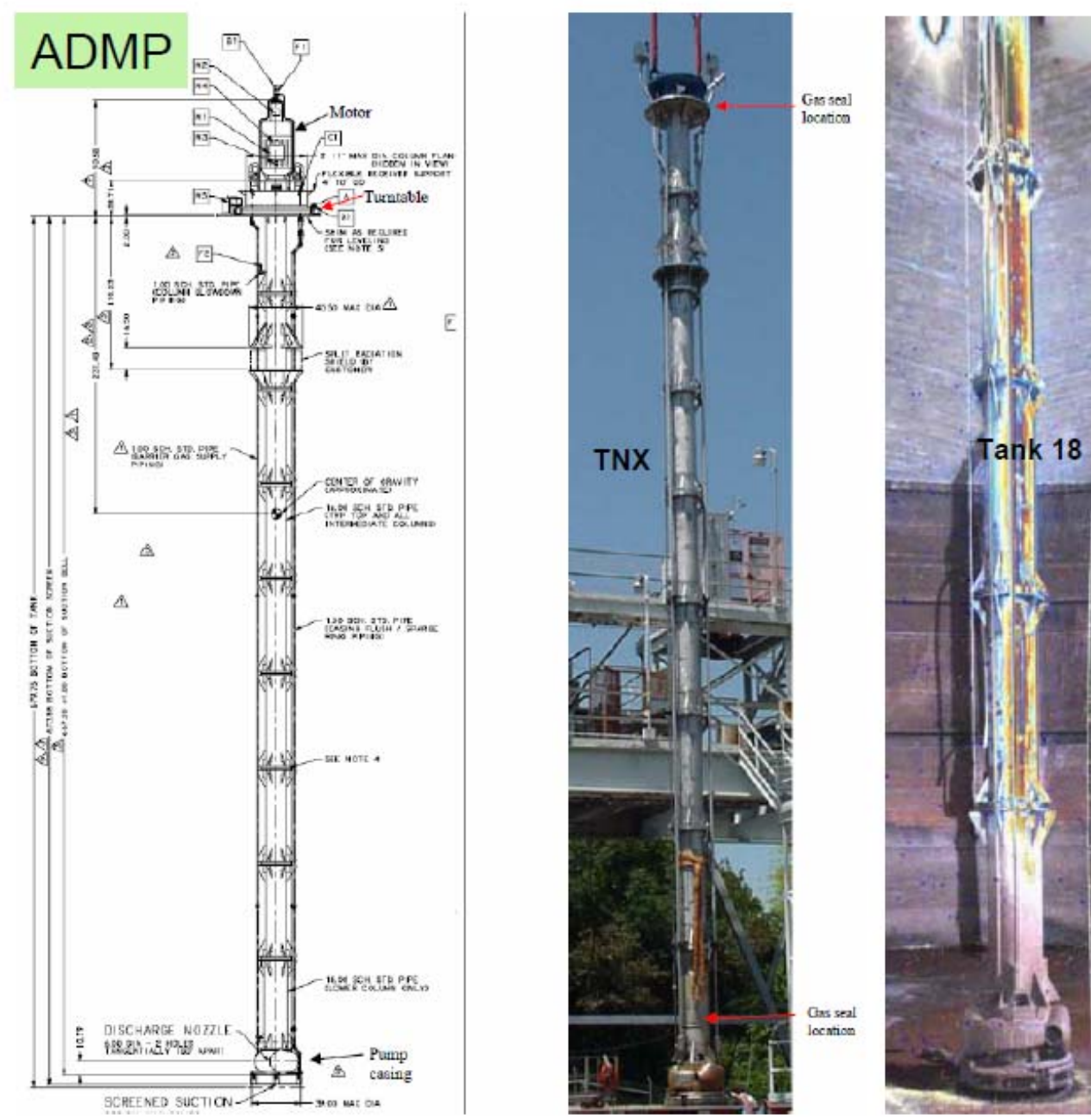

Figure 3-1. Advance Design Mixer Pump 


\subsubsection{ADMP Support Column}

The ADMP support column is made up of nine (9) column sections. It serves the function of supporting the rotating element, pump casing and transmitting unit rotation to the impeller. Each column section is an independent module containing a shaft and rolling thrust/radial bearing assembly. The seven (7) column sections are 74 inch in length. The upper column and lower column are shorter, 68 inch and 70 inch, respectively. There are four column configurations: 1) the upper column, 2) radiation shield support column, 3) intermediate column, and 4) the lowest column. All column sections are 16 inch schedule standard pipe with the exception of the lowest column which is 18 inch schedule standard pipe. Column pipe material is 304/304L stainless steel. Twelve 1 inch ASTM A193 B8 strain hardened bolts are used to join column sections at flanges. The seal for the column joint is a 304 stainless steel o-ring.

The upper column assembly is shown in Figure 3-2. Inside the upper column are a shaft and two (2) bearing housing assemblies. The bearing housings are bolted to two stainless steel disks welded inside the 16 inch pipe column. The mounting disks are 1 inch thick and machined for a close fit with its perspective bearing housing. Each mounting disk contains a 1.5 inch hole. Holes are not coincident and drilled at opposite sides of the shaft centerline on a 6.38 inch radius. Welded to the upper column is a short section of 1 inch piping for a pressure relief device. The relief device is shown to the left in Figure 3-2. A larger pressure relief device and rupture disk was originally connected to the lowest column by a 40 foot long pipe but SRS changed the configuration. The piping was removed and a pipe cap welded at the lower column cut off point $[11,12]$.
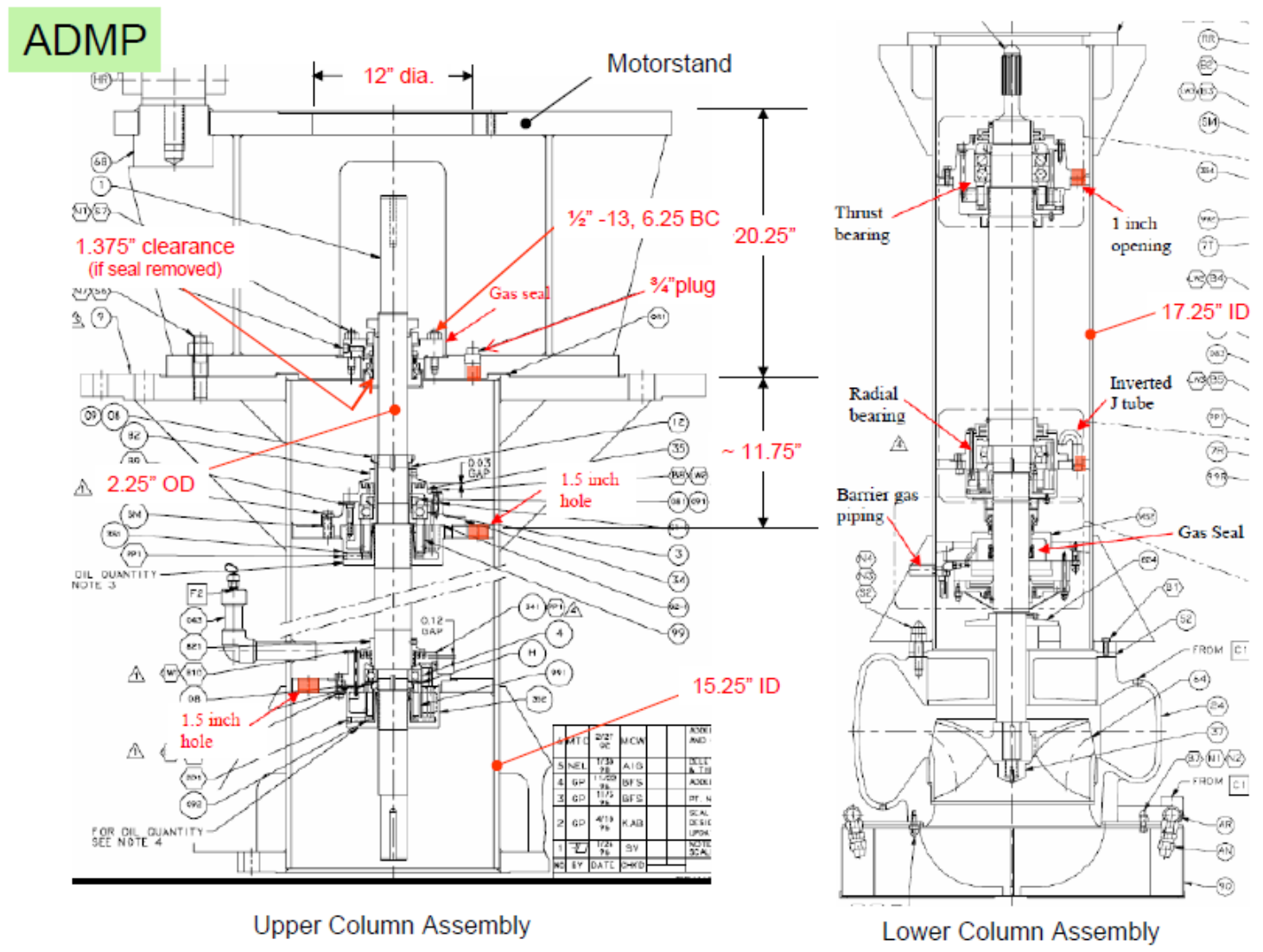

Figure 3-2. ADMP Upper and Lower Column Assemblies showing shafts, bearing arrangements, pressure protection device, motor stand, gas seals and pump. 
Bolted to the upper column is a motor stand. Inside the motor stand is a gas mechanical seal. The gas seal provides containment and allows the support column to be pressurized. A $3 / 4$ pipe plug is shown to the right of the gas seal. Two rectangular openings in the motor stand provide access to the upper pump shaft, gas seal, and $3 / 4$ pipe plug. Additional access to this region is available when the motor is not installed. The upper end of the shaft is keyed for the pump half of the motor coupling. The pump half of the motor coupling is not a shrink fit to the shaft.

Located at the right in Figure 3-2 is a cross-section of the lower column assembly. The shaft assembly for the lower column has larger bearings and shaft than the rest of the support column sections. Thrust produced from the impeller is handled by the upper bearing arrangement. The bearing closer to the impeller is for radial loads. Both bearing housings are bolted to plates inside the column. The mounting plate for the thrust bearing includes a 1.5 inch diameter opening yet the bearing housing partially covers the hole and reduces the opening size to 1.0 inch. Figure 3-3 shows a photo of the opening restriction at the thrust bearing of the lower column.

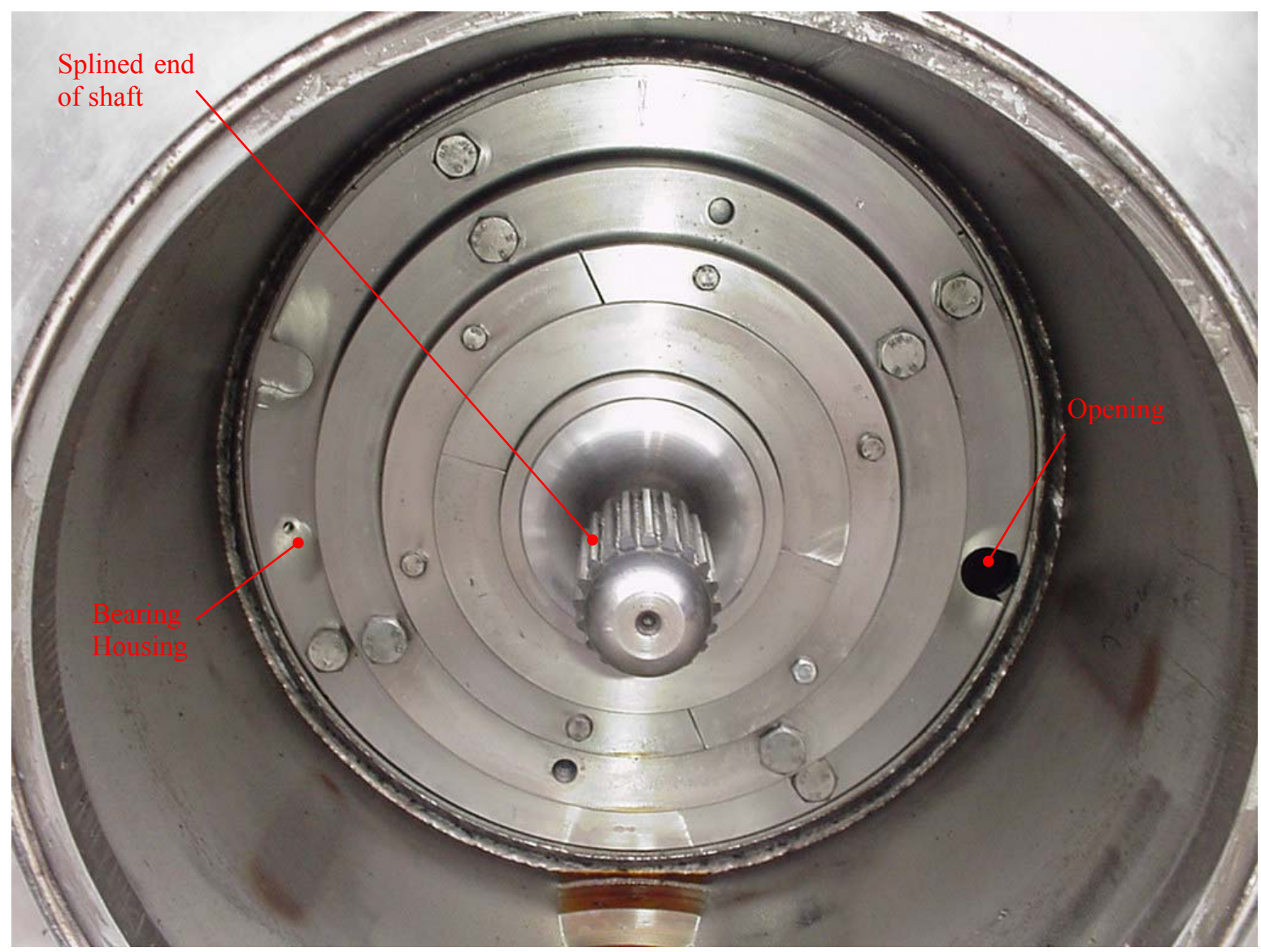

Figure 3-3. Lower ADMP Support Column (motor side) showing 1.0 inch opening restriction at thrust bearing location 


\subsubsection{ADMP Pump Casing}

The manufacturer designed the hydraulic pump casing with two, 6 inch diameter nozzles. The outlet nozzles, or jets, are arranged tangential, located at 180 degrees to each other and point in opposite directions. Figure 3-4 shows the pump casing and one of the nozzles.
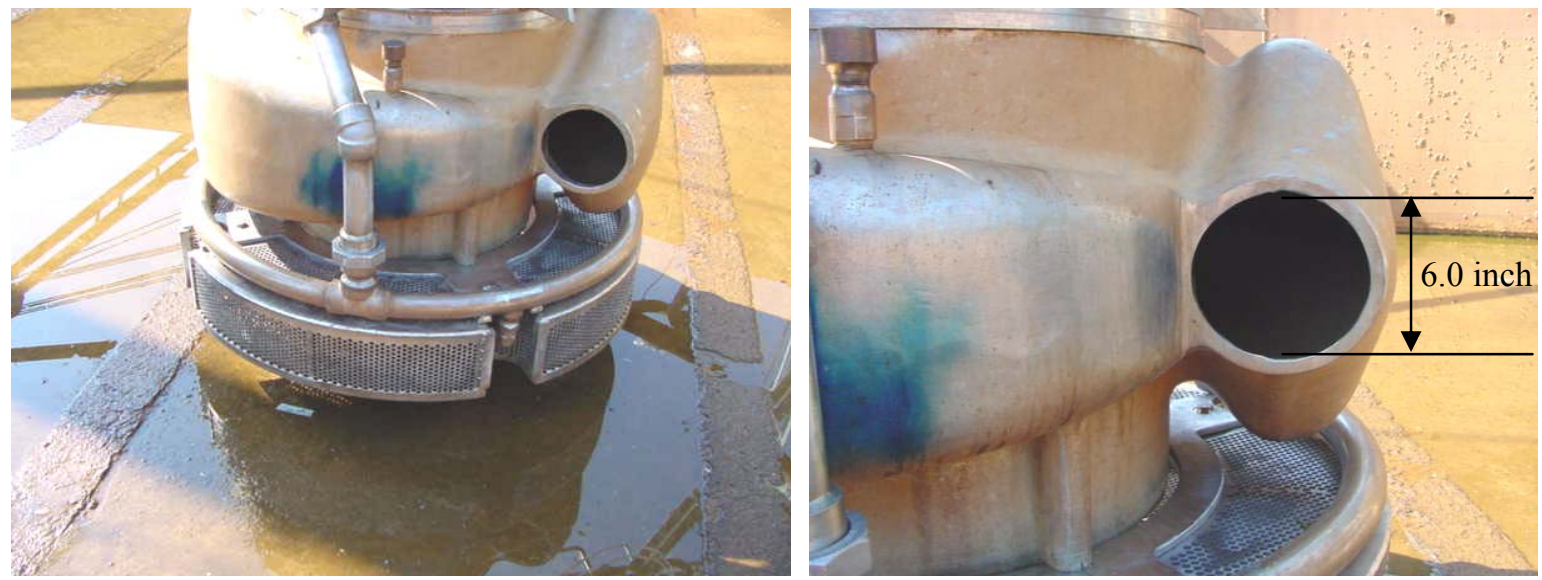

Figure 3-4. ADMP pump casing showing a nozzle, pump inlet screen, sparger ring and water supply piping

Located within the pump casing is the impeller connected to a shaft. Figure 3-5 shows 2 views of the ADMP impeller with the pump casing removed. The inlet/suction side of the impeller is shown at the left in the figure and has 7 blades. The picture at the right shows the impeller discharge openings. The discharge openings could be felt when reaching into the 6 inch nozzle of the pump casing.

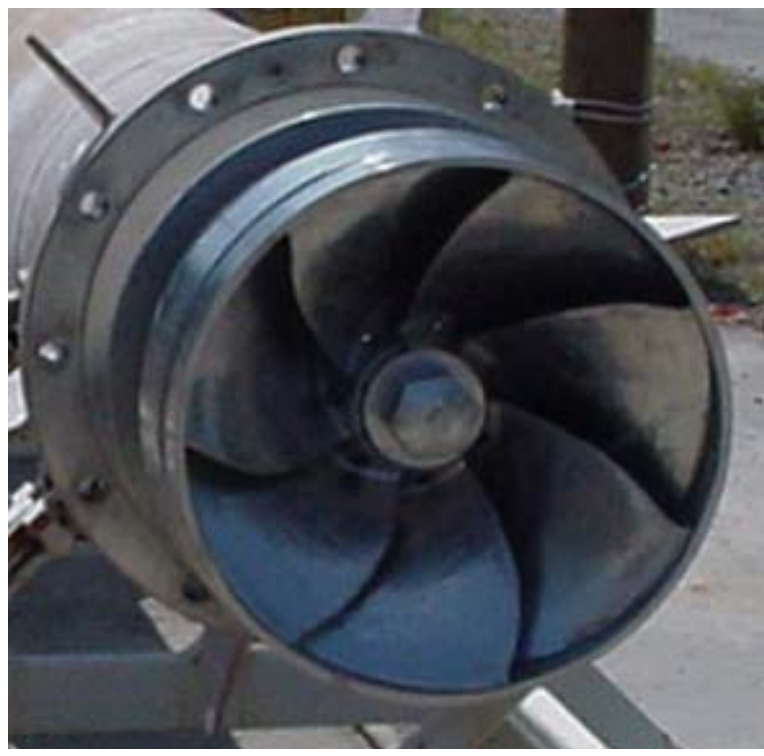

Suction Side

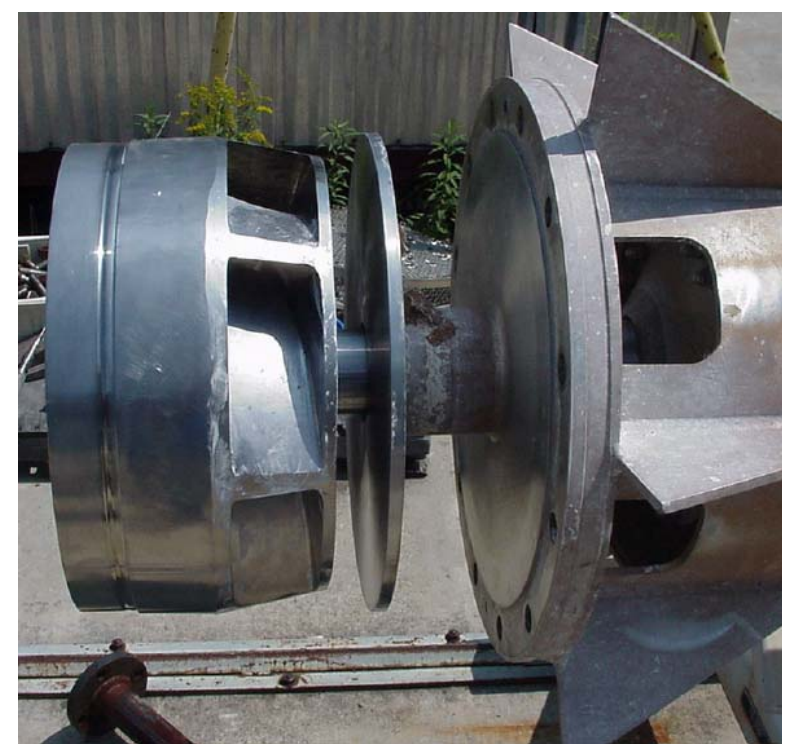

Discharge Side

Figure 3-5. ADMP Impeller 
Mounted below the pump casing and shown in Figure 3-6 is a sparger (or mining ring). The ADMP sparger is fabricated using 1.5 inch standard pipe, has four (4) spray nozzles/jets and was designed for mining the pump into the waste tank during installation. Sparger nozzle openings are $1 / 4 \mathrm{inch}$. Figure 3-6 shows process water being pumped through 2 of the spray nozzles for this component. Water is supplied to the sparger from a connection at the tank top.

The pump inlet screen is also visible in Figure 3-6. Screen openings in the figure are $3 / 8$ inch in diameter. A portion of these openings were modified after several hours of equipment operation in Tank 18. Debris inside the waste was plugging the screen and reducing the hydraulic performance of the pump. This, in turn, reduced the effectiveness of the equipment during waste removal operations.

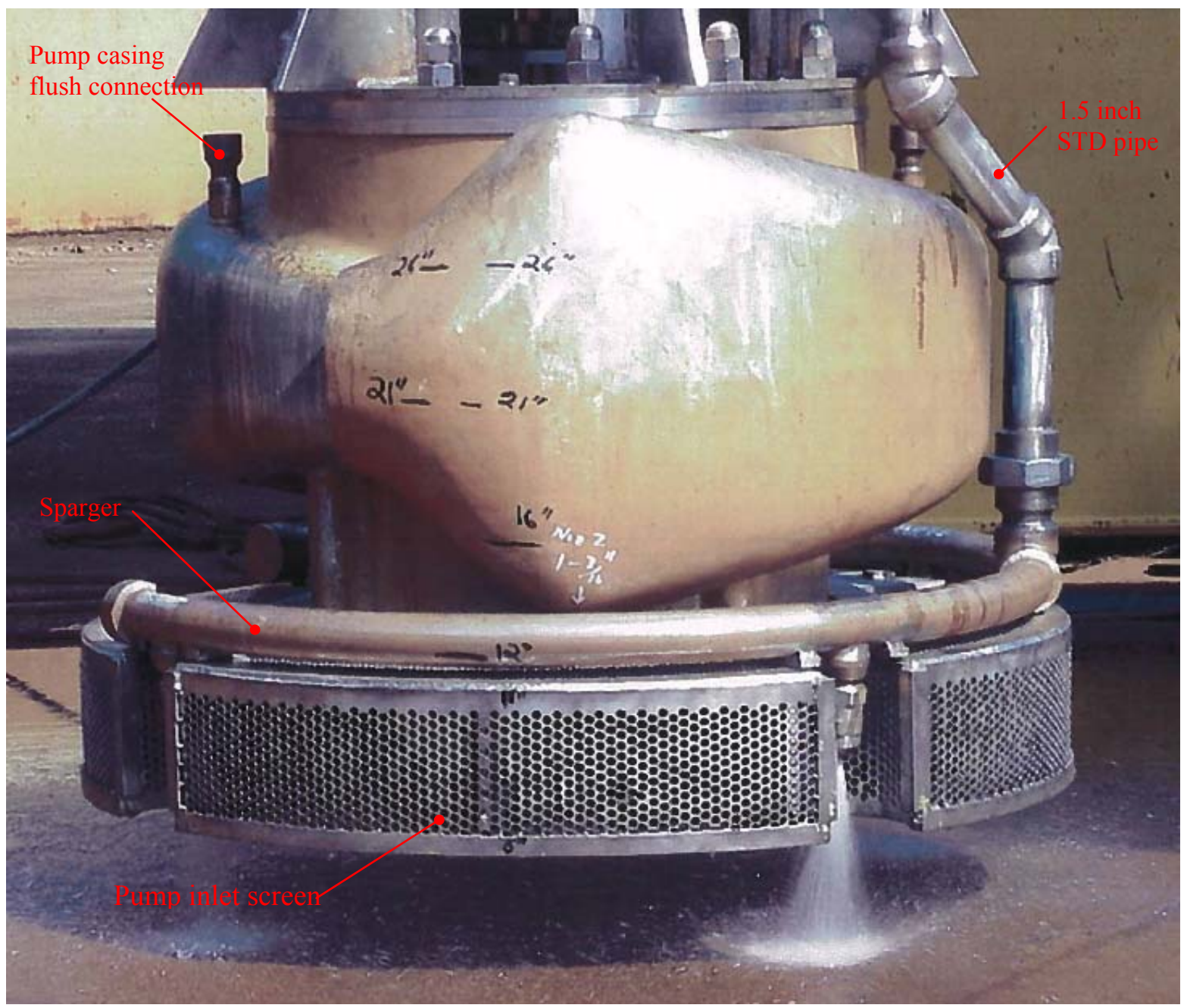

Figure 3-6. ADMP Sparger (or mining ring) shown spraying process water through 2 of 4 nozzles. The pump casing flush connection is isolated.

Changes made to the pump inlet screen are shown in Figure 3-7. Stainless steel wire mesh with $3 / 4$ inch square openings was used for the modification. No changes were made to the top portion or bottom portion of the screen. The photos taken were from inside the waste tank. 

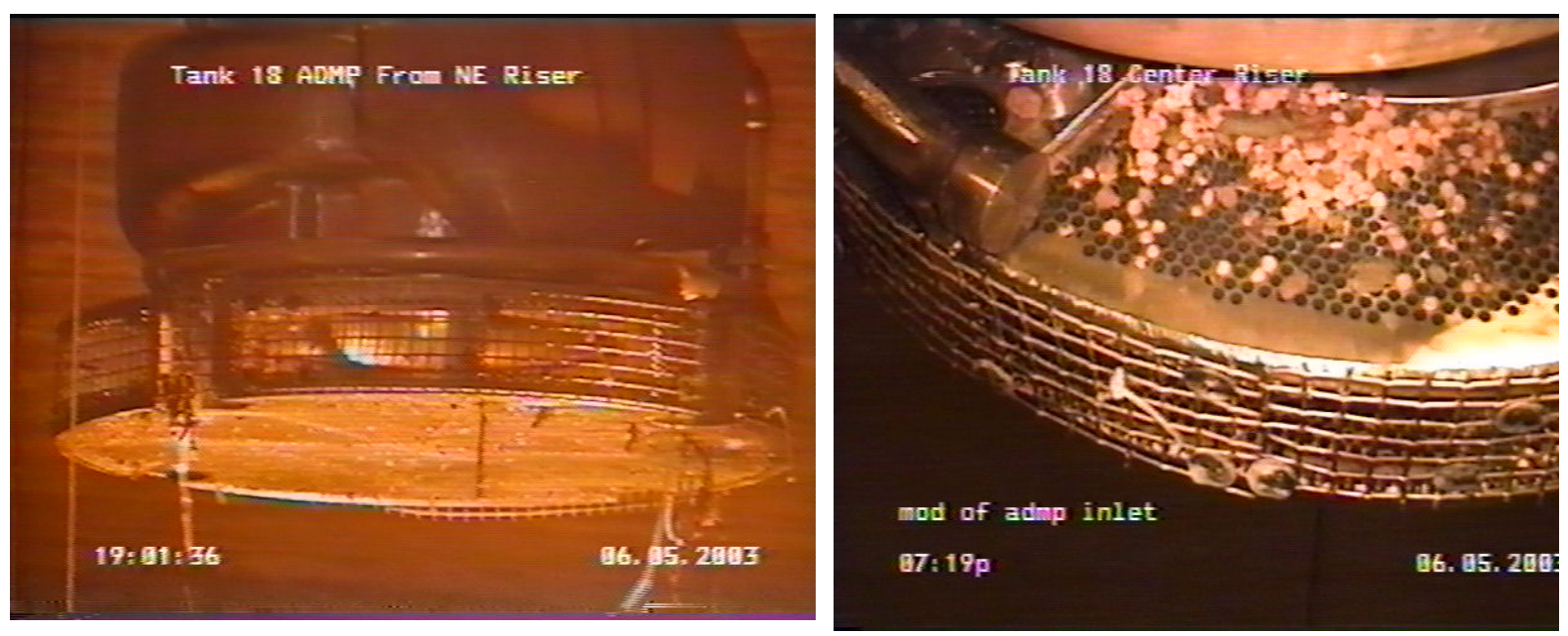

Figure 3-7. ADMP suction screen opening modification (post Tank 18-F installation).

\subsubsection{ADMP Rotor}

The rotating part of the ADMP, or rotor, includes nine (9) shaft assemblies. The upper shaft and intermediate shaft assemblies use deep groove ball bearings; a 6215 thrust bearing and 6212 radial bearing. The shaft diameter between bearings is 2.75 inch. The lower shaft between bearings is 5 inch in diameter and uses a duplex arrangement angular contact thrust bearing and a self aligning spherical roller radial bearing. Bearings are oil lubricated within sealed bearing housing assemblies. Each assembly has its own internal reservoir and impeller to circulate the oil. Radiation resistant oil was used (Synrad 1250 by Nye Lubricants). A 6212 bearing housing can be seen in Figure 3-8. The housing is attached to an intermediate shaft.

Intermediate shafts are splined at one end and machined for a key at the opposite end. A flexible coupling is interference fit to the keyed end of the shaft. The coupling arrangement can be seen in Figure 3-8. There are eight (8) couplings installed in the ADMP support column, one at each column joint. The coupling in the photo shows the hub was machined for the splined end of a shaft.

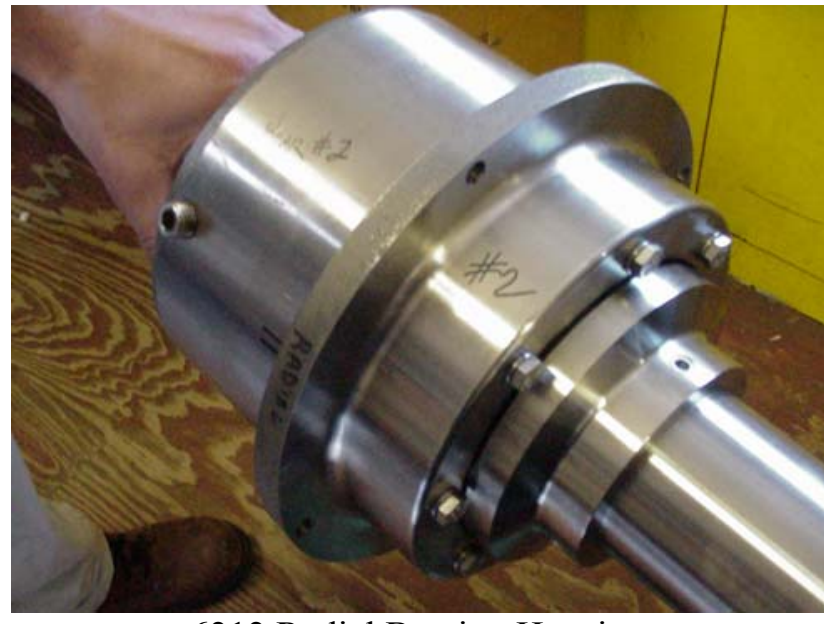

6212 Radial Bearing Housing for Upper and Intermediate Shafts

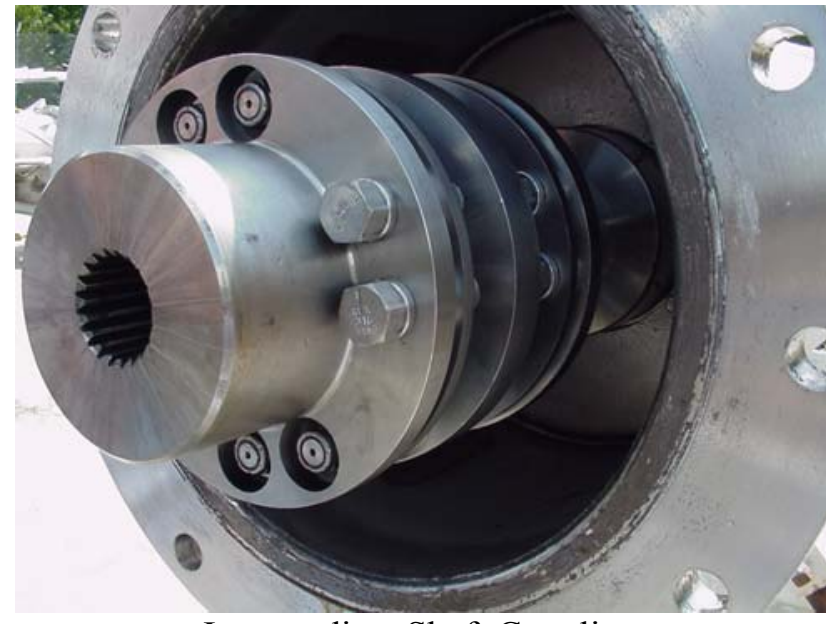

Intermediate Shaft Coupling at Column Joint

Figure 3-8. ADMP Rotor Components 


\subsection{EXPERIMENTAL SET UP}

\subsection{Test Location}

The URS Civil Engineering Test Laboratory in 717-5N was selected for the Tier 1A equipment grout mock up test since the work was within the scope of routine services provided to SRR and SRNL /SRNS. Many of the supplies, test equipment and materials were already available in the laboratory and waste disposal was addressed in the Environmental Evaluation Checklist (EEC) for the N-Area Civil Engineering Laboratory [13].

\subsection{Test Forms}

Drawings and photographs of the ancillary equipment that will remain in Tanks $18-\mathrm{F}$ and $19-\mathrm{F}$ were reviewed to design a test form that represented a set of boundary conditions for filling the internal volumes of these pieces of equipment with grout. The ADMP was determined to be the most problematic piece of equipment to fill. Based on the description of the ADMP provided in Section 3, an initial $8 \mathrm{ft}$ high scaled mock up with 18 chambers was designed and constructed by SRR Construction personnel for a Tier 1 test. However, due to limited materials, grout batching capabilities, and logistics for filling an $1 \times 1 \times 8 \mathrm{ft}$ high form, the form was cut in half and the bottom $4 \mathrm{ft}$ section was used for the Tier 1A test. Descriptions are presented below.

\subsubsection{ADMP Tier 1A Mock Up}

The 4 cubic foot test form and funnel fabricated by SRR to demonstrate gravity filling of the ADMP column with grout are shown in Figure 4-1 (a). The Plexiglas form was partitioned into 9 chambers with Plexiglas dividers/shelves. The form had two chamber volumes that alternated to mimic the ADMP. Each chamber divider except the bottom one had 1.5 inch opening for fluid and air flow. The divider immediately above the lowest chamber had the 1.0 inch hole. Two outlets were located near the bottom of the form for draining the form. One outlet consisted of 2 inch piping and a ball valve.

Sealant was used during fabrication to ensure filling and venting through the same opening. The top of the form had two holes, 1 inch and $3 / 4$ inch. The larger opening was for the funnel and the other opening served as a vent.

SRR Construction provided three funnels for use in demonstrating gravity filling of the ADMP mock up form. The funnels were identical except for the discharge openings. The opening sizes provided were 1 inch, $3 / 4$ inch, and $1 / 2$ inch. Material was galvanized steel and rivets used as fasteners. Sealant was applied at the seams and unistrut supports were used for holding the funnel in position above the ADMP mock up form. The funnels are shown in Figure 4-1 (b and c). 


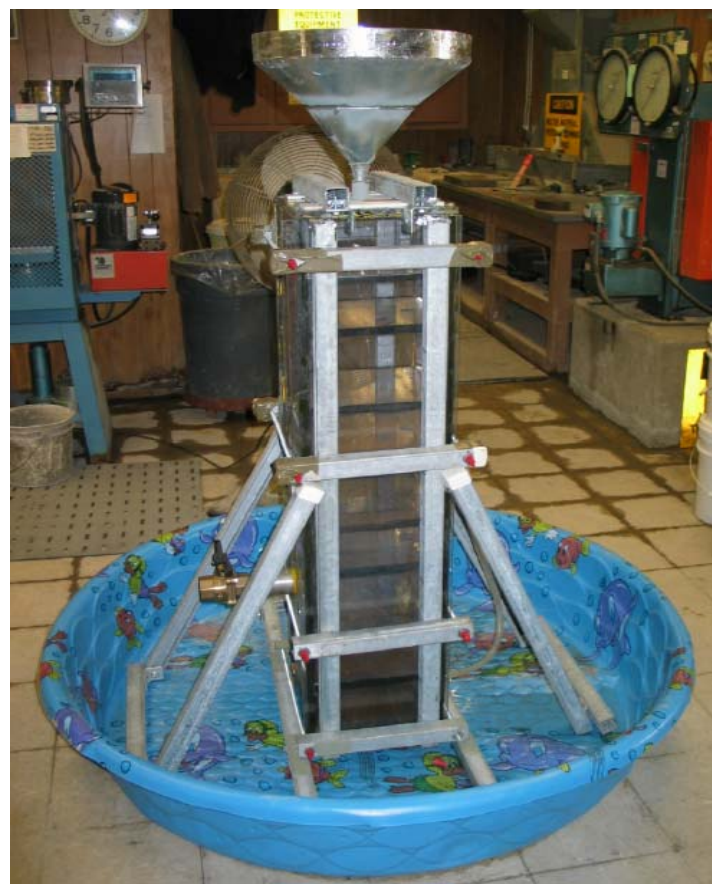

(a)

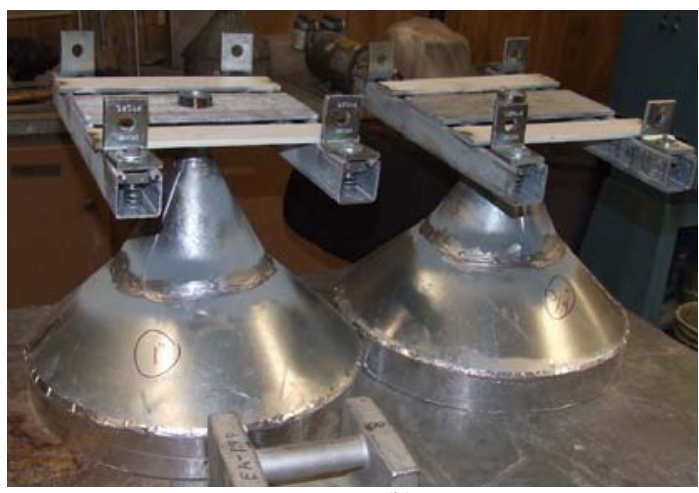

(b)

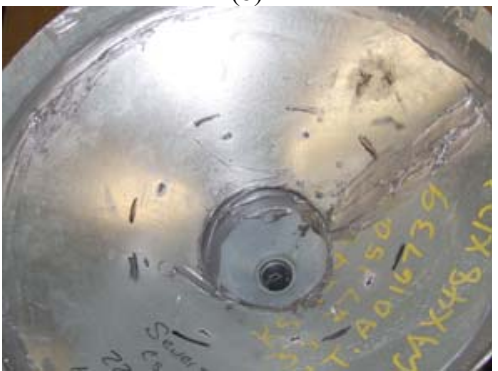

(c)

Figure 4-1. ADMP Mock Up form (a) and Funnels for Gravity Filling ADMP Mock Up (b and c).

\subsubsection{Pipe Mock Ups}

The set up for demonstrating grouting of 1 inch and 2 inch pipes is shown in Figure 4.2. Four pipes with caps at the end were used for the test. Each section of pipe was five feet long and arranged vertical as shown. Two of the pipes had stainless tubes inserted. The bottoms of these tubes were cut at a 45 degree angle and inserted the length of the pipes. Two sizes of tubing were set up for the demonstration, $3 / 4$ inch and $1 / 2$ inch. The larger tubing was placed inside the 2 inch pipe. The tubes were connected to a manual grout pump which is shown in Figure 4-2(b). Two funnel sizes are also shown. The larger funnel had a 1/2 inch opening and was positioned in 2 inch pipe. The smaller funnel had a $1 / 4$ inch opening and placed inside the 1 inch pipe. See Figure 4-2(a). The plastic tubing connected to the grout pump was $1 / 2$ inch diameter and 25 feet long. A Swagelok ${ }^{\circledR}$ tee and quick release valve were also part of the set up.

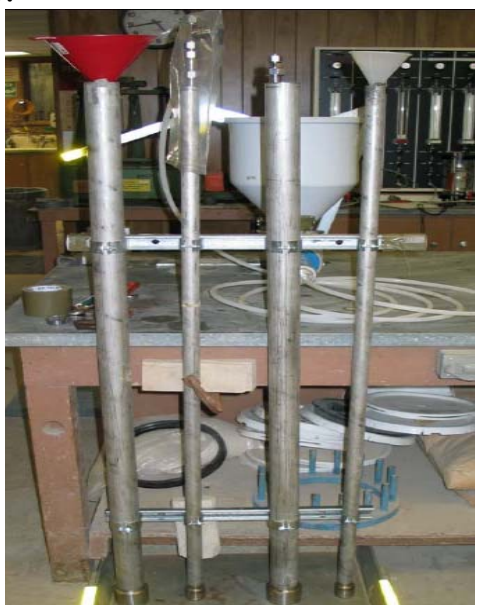

(a)

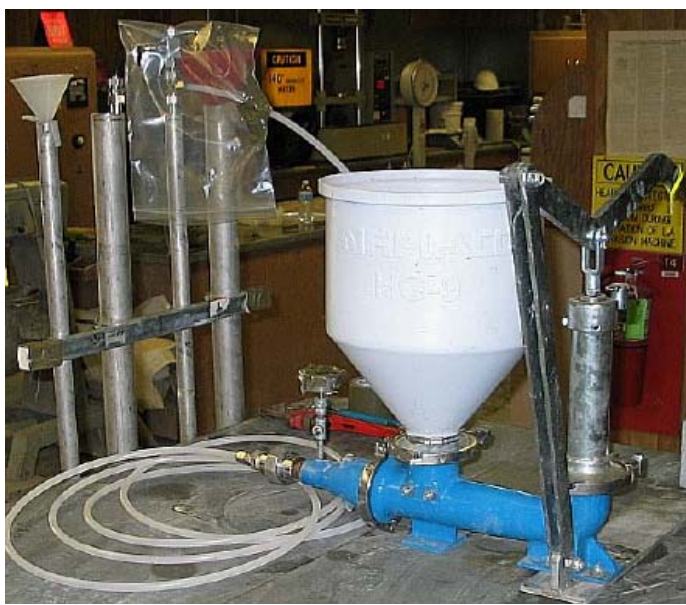

(b)

Figure 4-2. Mock up for grouting 1 inch and 2 inch pipes by gravity and pumping. 


\subsection{Equipment Grout}

\subsubsection{Base Case Cooling Coil Grout}

The cooling coil grout identified in WSRC-STI-2007-00641 was selected as a base case per the TTR [4]. This grout is a mixture of MasterFlow 816 cable grout (67.67 wt. \%), Grade 100 slag ( 7.52 wt. \%) and water (24.81 wt. \%) and was evaluated for filling ancillary equipment per the TTR for this work [4]. However, testing indicated that the adiabatic calorimeter results for the cooling coil grout exceeded $100^{\circ} \mathrm{C}$. (Under sealed conditions where steam is not able to escape, the estimated maximum temperature was calculated to be $127^{\circ} \mathrm{C}$.) Consequently it was not selected for filling the larger ancillary equipment in Tanks 18 and 19-F. The minimum formulation design change was determined to consist of diluting the cooling coil grout with inert filler, i.e., Class F fly ash to reduce the heat of hydration. This was done without considering the consequences to cured properties. A calorimeter plot for cooling coil grout is provided in Figure 4-3. Water adjustments were also required during the reformulation process. (Redesign of the equipment formulation should result in a material with improved cured properties.)

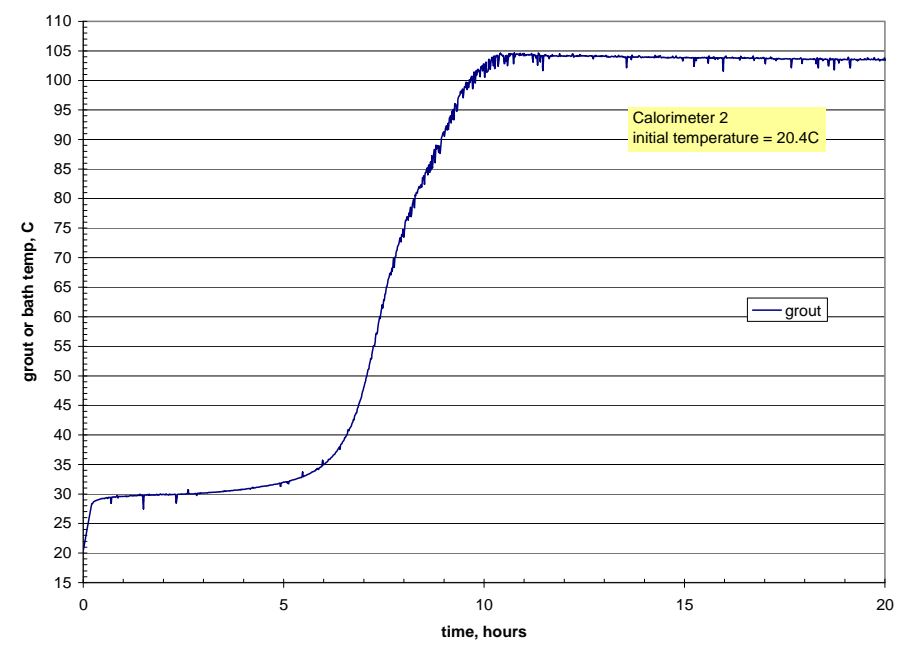

Figure 4-3. Calorimeter Temperatures for Coiling Coil Grout for MF816-1H.

\subsubsection{Fly Ash Adjusted Cooling Coil Grout for Mock up Test}

Two fly ash-adjusted cooling coil (MasterFlow 816 grout + Grade 100 slag) grout compositions were selected for the Tier 1A equipment testing. These mixes were selected from a series of trial mix designs because a 16 second flow cone value was achievable for fly ash and water dilutions that produced material with 28 day compressive strengths of at least 2000 psi. Ingredients and proportions are provided in Table 4-1.

Table 4-1. Tier 1A Grout Formulations (by mass fraction)

\begin{tabular}{|l|c|c|}
\hline Ingredient & T1a-62.5FA & T1a-75FA \\
\hline Masterflow $^{\circledR} 816$ & 24.35 & 16.24 \\
\hline Blast Furnace Slag, Grade 100 & 6.50 & 6.49 \\
\hline Fly Ash, Class F, ASTM C618 & 40.59 & 48.69 \\
\hline Domestic Water & 28.57 & 28.58 \\
\hline w/cm & 0.40 & 0.40 \\
\hline
\end{tabular}


The Masterflow ${ }^{\circledR} 816$ was obtained from BASF, Inc., and is an aggregate free grout formulated for applications requiring a fluid, shrinkage-compensating material for filling small spaces, e.g., around pretensioned or post-tensioned cables and rods. The ready-to-use packaged product is specially formulated for pumping, and applications where recirculation for several hours may be necessary. The Masterflow ${ }^{\circledR}$ 816 product consistently set without settlement or bleed even though about $30 \%$ extra water was added. Masterflow ${ }^{\circledR} 816$ contains more than $60 \%$ Portland cement, which explains the high temperatures during curing, and high early compressive strengths. Grade 100 blast furnace slag is also cementitious and was obtained from Holcim, Inc., Birmingham, AL. The Class F fly ash meets ASTM C618 standards and was obtained from the SEFA, Inc. and was generated at the Wateree power plant. N-Area domestic water was used to prepare the grout.

\subsection{Grout Production Strategy and Batch Size}

Dry ingredients were pre-weighed and placed in twelve, 5 gallon buckets. Each bucket received enough solids to make about 3.2 gallons of grout slurry. Six buckets were prepared for each formulation. The mix water was also staged in buckets before the test. Figure 4-4 shows the approach. One bucket from each batch was used for characterization testing. The other buckets were used to fill the forms.
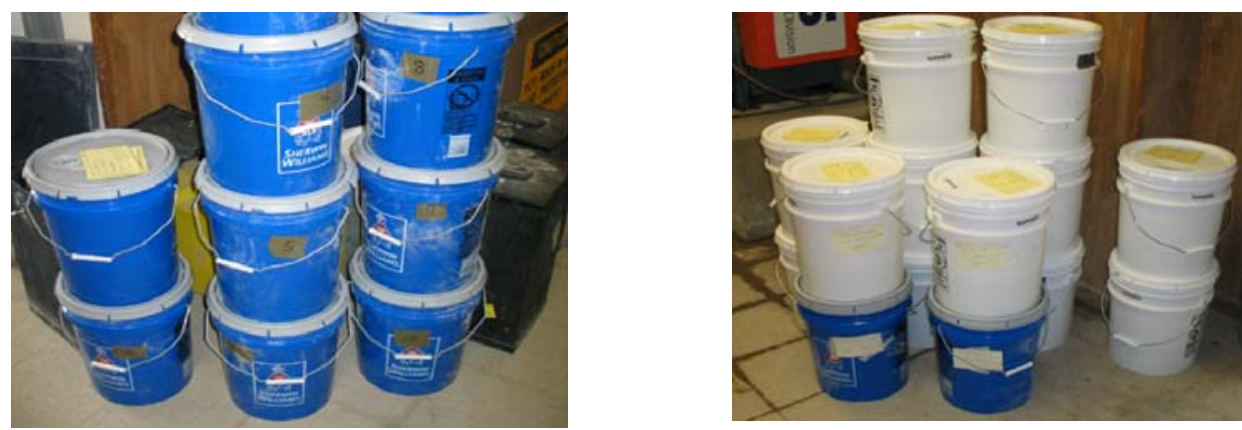

Figure 4-4. Preparation of Mix Ingredients

\subsection{Method of Mixing}

Two mixing techniques were used to support testing. Paddle mixing with a drill auger was used for initial wetting of the powder. The dry powder was added to the water while stirring for 3 minutes. The bucket of grout slurry was then sheared for 30 seconds using a bench top laboratory mixer (Ross HSM$100 \mathrm{~L}$ with disintegrating head). The equipment used to prepare the grout is shown in Figure 4-5.

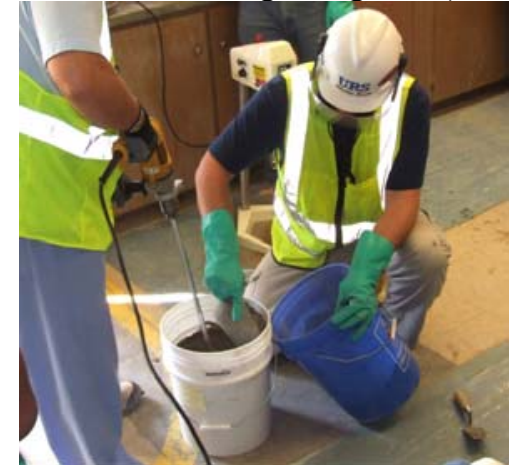

(a)

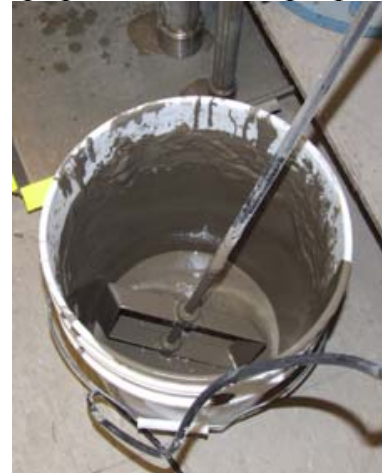

(b)

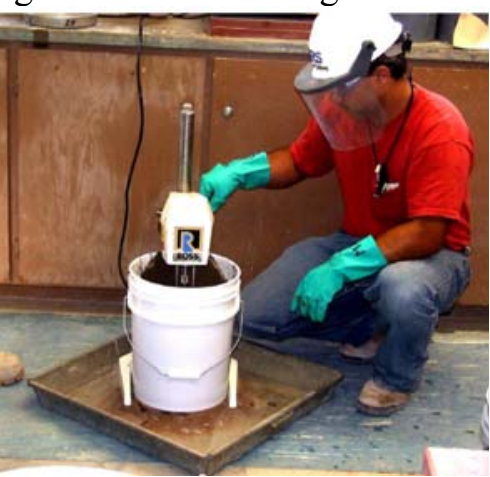

(c)

Figure 4-5. Paddle mixing (a and b) and colloidal (shear) mixing (c) 


\subsection{Fresh and Cured Property Measurements}

Several property measurements were identified in the test plan as part of the Tier 1A equipment fill mock up. Properties and test methods used to characterize the grout prepared for the mock up test are listed in Table 4-2.

Table 4-2. Fresh and Cured Property Tests

\begin{tabular}{|c|c|c|}
\hline Property & Test Method & Remark \\
\hline $\begin{array}{l}\text { ASTM Flow Cone } \\
\text { (after paddle mixing) }\end{array}$ & \multirow[t]{2}{*}{ ASTM C939 } & \\
\hline $\begin{array}{l}\text { ASTM Flow Cone } \\
\text { (after shear mixing) }\end{array}$ & & \\
\hline $\begin{array}{l}\text { Static Flow (initial spread and at } \\
\text { select time intervals) }\end{array}$ & $\begin{array}{l}\text { SRNL modified ASTM } \\
\text { D6103-04 }\end{array}$ & $3 \times 6$ cylinder \\
\hline Grout Temperature & ASTM C1064 & \\
\hline Ambient Temperature & $\begin{array}{l}\text { Temperature readout device } \\
\text { within test boundary }\end{array}$ & Not required in test plan. \\
\hline Unit Weight (lb/cu ft) & ASTM C138/C138M - 10 & \\
\hline Air Content (vol.\%) & ASTM C231/C231M - 10 & \\
\hline Mixing & Stop watch & $\begin{array}{l}\text { Using to control paddle } \\
\text { mixing and shear mix times }\end{array}$ \\
\hline Bleed (ml) & ASTM C232/C232M - 09 & $\begin{array}{l}\text { Checked with syringe } 24 \\
\text { hours after poured }\end{array}$ \\
\hline $\begin{array}{l}\text { Compressive Strength } \\
7,28 \text { and } 90 \text { days }\end{array}$ & ASTM C39/C39M - 11 & $4 \times 8$ cylinder \\
\hline Shrinkage/cracking & $\begin{array}{l}\text { Visual exam of slices taken } \\
\text { from } 1 \text { inch and } 2 \text { inch mock } \\
\text { up pipes after grout cures }\end{array}$ & $\begin{array}{l}\text { No requirement in PA. For } \\
\text { development purpose only. }\end{array}$ \\
\hline $\begin{array}{l}\text { Saturated Hydraulic Conductivity } \\
\text { after } 90 \text { days of curing }\end{array}$ & ASTM D5804-10, Method C & $\begin{array}{l}\text { Method F may be performed } \\
\text { at MACTEC on cured sample } \\
\text { (optional) }\end{array}$ \\
\hline Time of Set & $\begin{array}{l}\text { ASTM C } 403 / 403 \mathrm{M}-08 \text { or } \\
\text { Ultra Sonic Pulse Velocity }\end{array}$ & \\
\hline
\end{tabular}

A stopwatch was used to measure the time for $1725 \mathrm{ml}$ of grout to flow through the ASTM flow cone. See Figure 4-6 (a). A flow cone measurement was taken for select batches after 3 minutes of paddle mixing and again after 30 seconds of shearing mixing. Prior to the test, water is run through the cone to verify the discharge takes 8 seconds. The cone was allowed to drain for 1 minute before re-testing the grout. The discharge tube was blocked with a finger and grout put into the cone until it filled to the tip of a pointer. Simultaneously, a stopwatch was started and the finger removed. The stopwatch was stopped at the first break in continuous flow from the discharge tube.

The static spread test was performed using $3 \times 6$ plastic cylinders which were open at both ends. These containers were placed on a 24 inch spread board and filled with grout. The cylinders were lifted (pulled) at select time intervals and the grout spread was measured in two directions and averaged. See Figure 4-6 (b). 


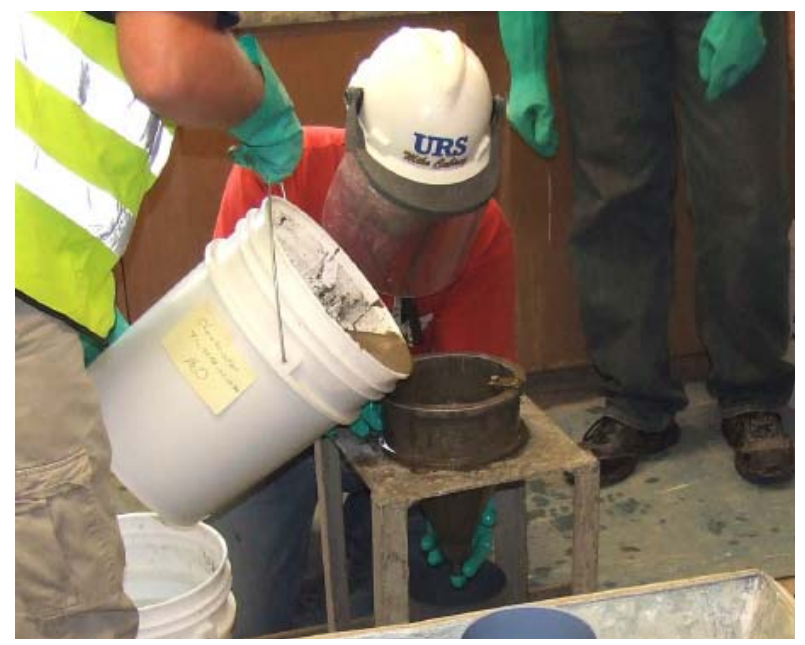

(a)

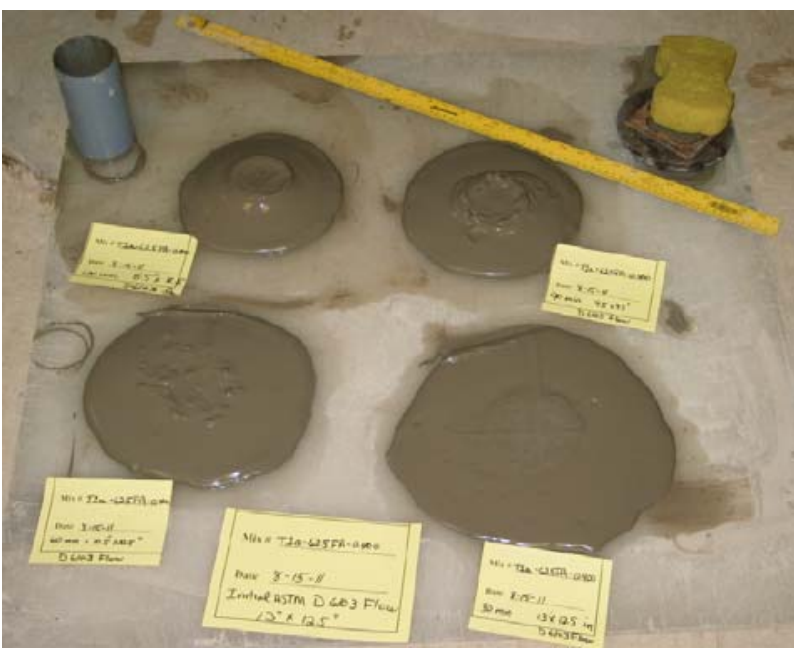

(b)

Figure 4-6. ASTM C939 flow cone (a) and modified D6103 Static flow test (b).

Grout temperature was checked using a thermometer designed for the application. A digital temperature display was also available to monitor ambient conditions in the lab for general information. The apparatus used for measuring volumetric air content in the grout is shown in Figure 4-7 (a). The pot portion was also used as the unit volume container for determining unit weight.

Samples for determining compressive strengths were cast in $3 \times 6$ inch plastic cylinders and capped. These samples were cured in a controlled environment. ${ }^{1}$ Samples for determining saturated hydraulic conductivity were poured in $2 \times 4$ inch cylinders and placed in the same curing environment. The compression tester and permeability cell are shown in Figure 4-7 (b) and (c), respectively.
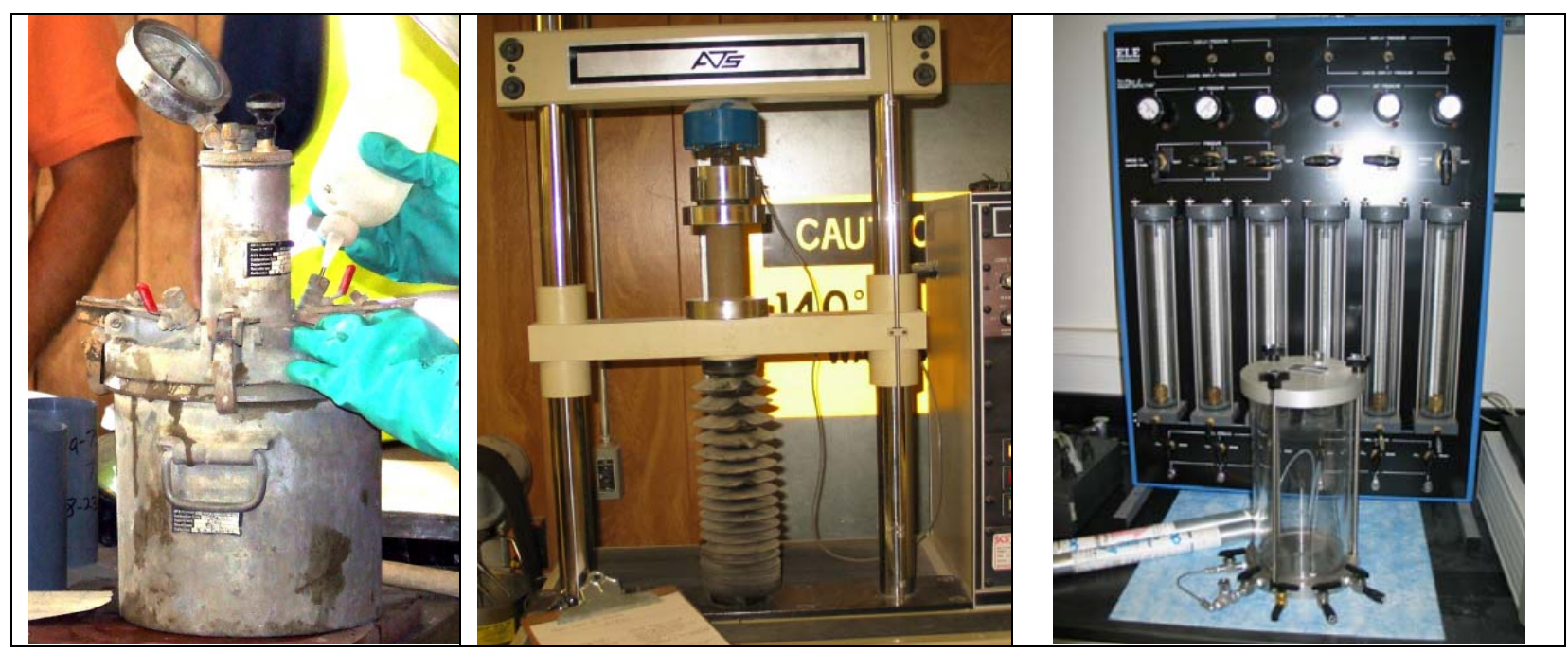

Figure 4-7. ASTM C231/C231M apparatus for determining air content (a), Compression tester (b) and hydraulic conductivity cell (c).

\footnotetext{
${ }^{1}$ Compressive strength was measured to characterize the equipment fill grout for information only. Equipment grout requirements are identified in a separate document [10].
} 


\subsection{RESULTS AND DISCUSSION}

The Tier 1A mock up evaluation consisted of three separate tests.

- Test 1 consisted of water runs through the ADMP mock up form and funnels. The objective was to evaluate the flow behavior through the mock up form so that a suitable funnel and funnel fill level (flow rate) could be identified for conducting the grout fill test.

- Test 2 involved preparing enough grout to characterize the material and fill the ADMP mock up.

- Test 3 involved gravity filling and pumping grout into the 1 and 2 inch pipe mock ups with material used to fill the ADMP 4 cubic ft. mock up form.

\subsection{Water Flow Tests}

The water run was performed using a funnel with a $1 / 2$ inch outlet. Tests were performed for two different water head levels (flow rates) using the funnel with the $1 / 2$ inch outlet. Level indicator marks were made inside the funnel at 9.0 and 14.5 inches above the spout outlet to achieve the two head pressures. Buckets were used to pour water into the funnel and maintain a fairly consistent liquid level. See Figure 5-1.

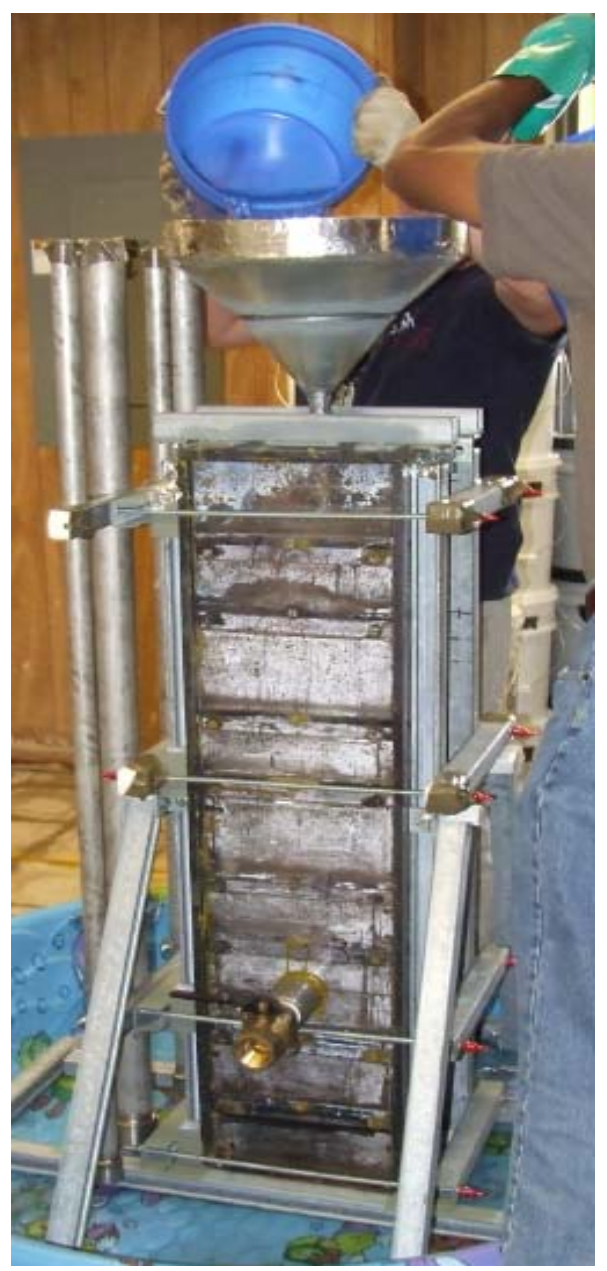

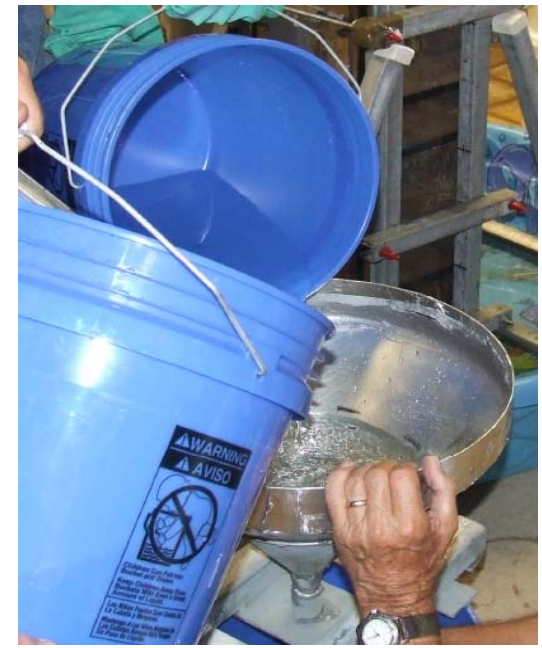

(b)

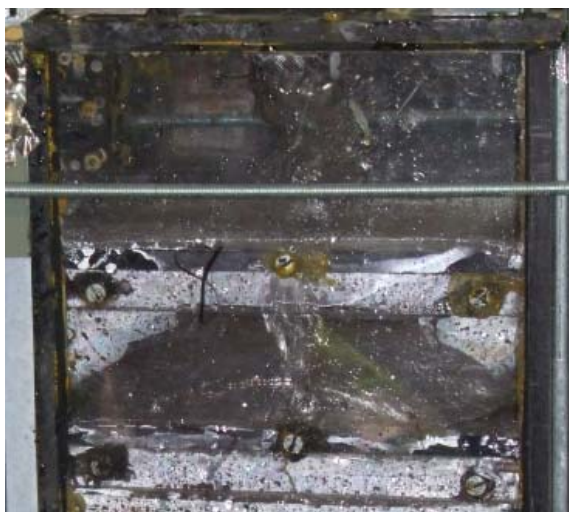

(c)

Figure 5-1. ADMP mock up form (a), Water run (b and c). 
In the first water test, the funnel was filled to the 14.5 inch mark. The water elevation in the highest chamber (chamber 9) of the mock up form began rising. Within 100 seconds, the top chamber flooded and, liquid began spilling out of the $3 / 4$ inch vent hole in the top plate of the form. The fill rate was slowed at that point and, filling continued at a reduced rate until the form was full.

At the higher flow rate, the second chamber from the bottom filled before the bottom chamber because the opening to the bottom chamber was $1 / 2$ inch less than the openings to all of the other chambers. The smaller opening did not allow the overlying chamber to discharge water as fast as the overlying second chamber was being filled. Test results are provided in Table 5-1.

The water level in the funnel for the second water test was reduced from 14.5 to 9 inches, thereby, reducing the flow rate into the mock up form (less head pressure due to shorter water column). During this test, the upper chamber did not overflow through the vent at the top of the mock up and, the chambers filled uniformly. Again, the second chamber from the bottom filled before the bottom chamber. Fill times for Chamber 2 and 1 were 94 and 120 seconds, respectively. The total time to fill the Tier 1 A form using the SRR funnel with a $1 / 2$ inch opening and a 9 inch head was 400 seconds (approximately 6.7 minutes). The times to fill each chamber for the two flow rates are provided in Table 5-1.

Table 5-1. ADMP Mock Up form water flow test for $1 / 2$ inch discharge opening SRR Funnel.

\begin{tabular}{|l||c|c||c|c|}
\hline \multicolumn{1}{|c||}{} & \multicolumn{2}{c||}{ TEST 1. 14.5 inch Head } & \multicolumn{2}{c|}{ TEST 2. 9 inch Head } \\
\cline { 2 - 5 } Top on form & $\begin{array}{c}\text { Time } \\
\text { (s) }\end{array}$ & \multicolumn{1}{c|}{ Comments } & $\begin{array}{c}\text { Time } \\
\text { (s) }\end{array}$ & Comments \\
\hline Chamber 9 & 342 & $\begin{array}{l}\text { Within 100 seconds } \\
\text { Chamber 9 flooded }\end{array}$ & 400 & Chamber 9 did not flood \\
\hline Chamber 8 & 333 & & 378 & \\
\hline Chamber 7 & 307 & & 347 & \\
\hline Chamber 6 & 278 & & 303 & \\
\hline Chamber 5 & 240 & & 274 & \\
\hline Chamber 4 & 195 & & 234 & \\
\hline Chamber 3 & 172 & & 145 & \\
\hline Chamber 2 & $<128$ & $\begin{array}{l}\text { Chamber 2 filled before } \\
\text { chamber 1 }\end{array}$ & 94 & $\begin{array}{l}\text { Chamber 2 filled before } \\
\text { chamber 1 }\end{array}$ \\
\hline Chamber 1 & 128 & & 120 & \\
\hline Bottom on form & & & \\
\hline
\end{tabular}

\subsection{ADMP Mock Up Form Grout Flow Testing}

After water was drained from the ADMP mock up form, it was dried over several days before the grout fill test. Ten buckets / batches of grout were used to fill the form in this test. The first five buckets of grout ( 2 cubic feet) contained Mix T1a-62.5FA. Buckets 6 to 10 contained Mix T1a-75FA. Both mixes had slurry rheologies that resulted in 16 second flow cone values (compared to 8 seconds for water).

The SRR funnel with the $1 / 2$ inch outlet was used for the grout test. The grout level was maintained at the 9 inch mark for rough control of the fill rate (head pressure). During the grout test, the bottom 
chamber filled first and the other chambers filled at an even rate. The gravity fill process took 500 seconds ( $\sim 8.3$ minutes) to fill 4 cubic feet in the $4 \mathrm{ft}$. high mock up form.

After filling, a flash light was held at one side of the box and the filled form was viewed from the opposite side to detect voids. All chambers were completely filled except one. A small horizontal gap $\left(<1 / 4\right.$ inch) at the top divider plate between the $3^{\text {rd }}$ and $4^{\text {th }}$ chambers was detected. The dividing plate may not have been completely level.

Chamber fill times for the grout test are listed in Table 5-2. The bottom chamber filled first which is different than the water run. A possible explanation is that the drain tube at the bottom of the form may not have been completely closed and thereby provided a second air vent pathway.

A general observation was that even though the flow cone measurement for both grout mixes was relatively low (16 seconds) these mixes had high viscosities (honey like) compared to grouts with higher water to cementitious materials ratios tested for other applications. The fly ash adjusted cooling coil grout mixes appeared sticky and although the four foot high form was filled from the bottom up, the potential for chamber flooding was apparent even with manual control of the fill rate and visual indication throughout the entire column to give warning of near flooded conditions. Chamber flooding did occur at the higher flow rate and the displaced air could not vent through a flooded chamber. This resulted in overfilling and rejection (spill) of grout around the funnel and air vent.

At a fill rate of no more than 4 gallons per minute (required to prevent chamber flooding) and given the long and tortuous flow path and long fill time involved in filling the 55 foot long column in the actual ADMP, a lower viscosity grout is recommended to increase the likely hood of complete filling and reduce risk of spills caused by chamber flooding.

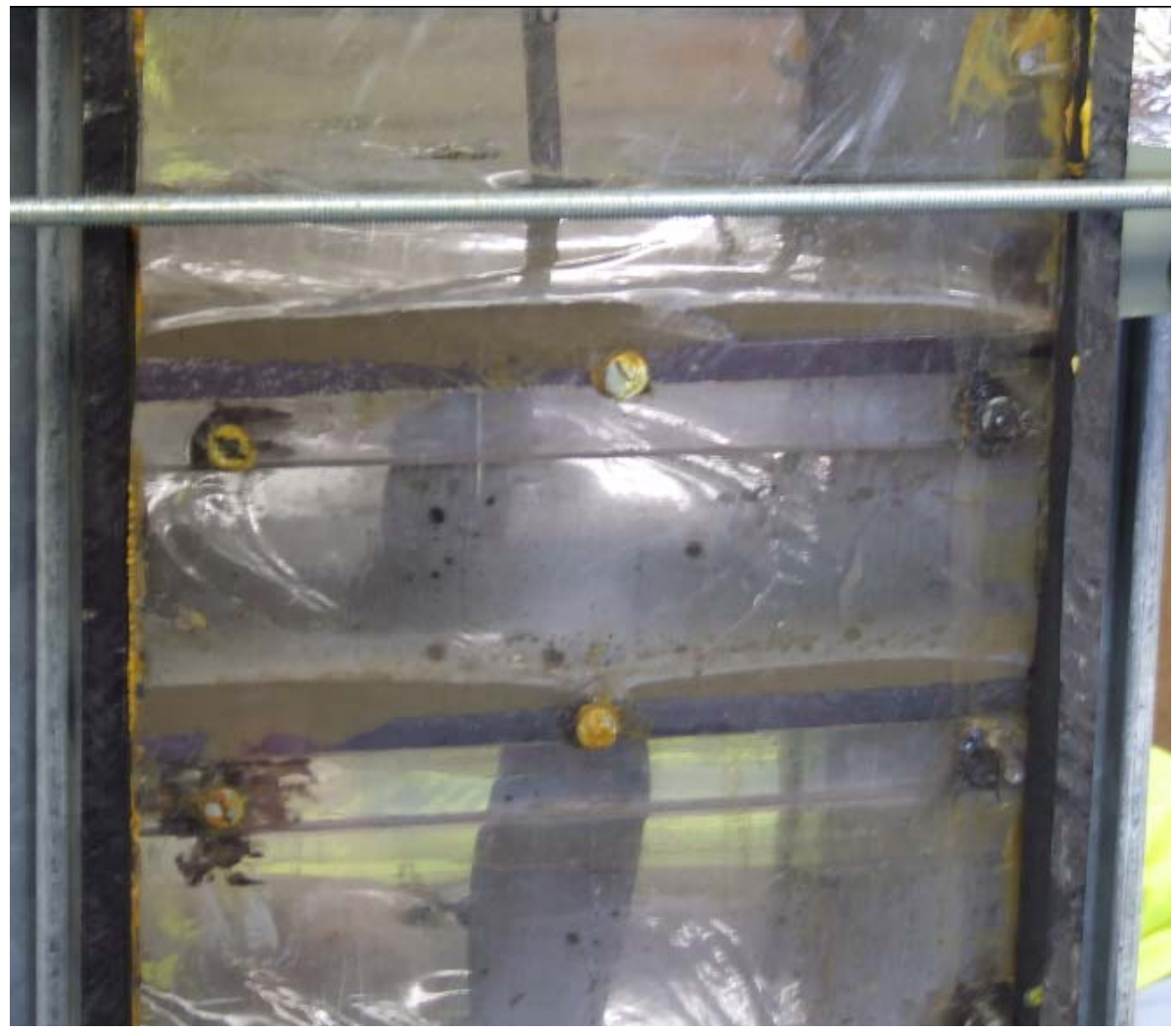

Figure 5-2. Tier 1A Test form being filled with Grout. 
Table 5-2. Grout fill times for chambers in the Tier 1A ADMP test form using a funnel with a $1 / 2$ inch ID spout opening to fill the form.

\begin{tabular}{|c|c|c|c|c|}
\hline \multirow[b]{2}{*}{ Top on form } & \multicolumn{2}{|c|}{ TEST 1. 14.5 inch Head } & \multicolumn{2}{|r|}{ TEST 2. 9 inch Head } \\
\hline & $\begin{array}{c}\text { Time } \\
\text { (s) }\end{array}$ & Comments & $\begin{array}{c}\text { Time } \\
\text { (s) }\end{array}$ & Comments \\
\hline Chamber 9 & NM & \multirow{9}{*}{$\begin{array}{l}\text { No Test. } \\
\text { Grout filling of } \\
\text { mockup test form not } \\
\text { performed at this } \\
\text { funnel-fill level } \\
\text { (head) based water } \\
\text { testing results and } \\
\text { since difficult to } \\
\text { clean test form }\end{array}$} & 500 & Upper chamber did not flood \\
\hline Chamber 8 & NM & & 455 & \\
\hline Chamber 7 & NM & & 420 & \\
\hline Chamber 6 & NM & & 390 & \\
\hline Chamber 5 & NM & & 360 & \\
\hline Chamber 4 & NM & & 330 & \\
\hline Chamber 3 & NM & & 290 & \\
\hline Chamber 2 & NM & & 255 & \\
\hline Chamber 1 & $\mathrm{NM}$ & & 180 & First chamber to fill \\
\hline Bottom on form & & & & \\
\hline
\end{tabular}

\subsection{Pipe Fill Mock Up Tests}

Results of the pipe filling tests are illustrated in Figure 5-3. Both pipes ( 1 and 2 inch ID) filled from the top down by gravity discharge through a funnel were completely filled. Both pipes (1 and 2 inch ID) filled from the bottom up by discharge through a tube inserted into the pipes were also completely filled. In all cases the displaced air in the pipes was vented through the tops of the pipes.

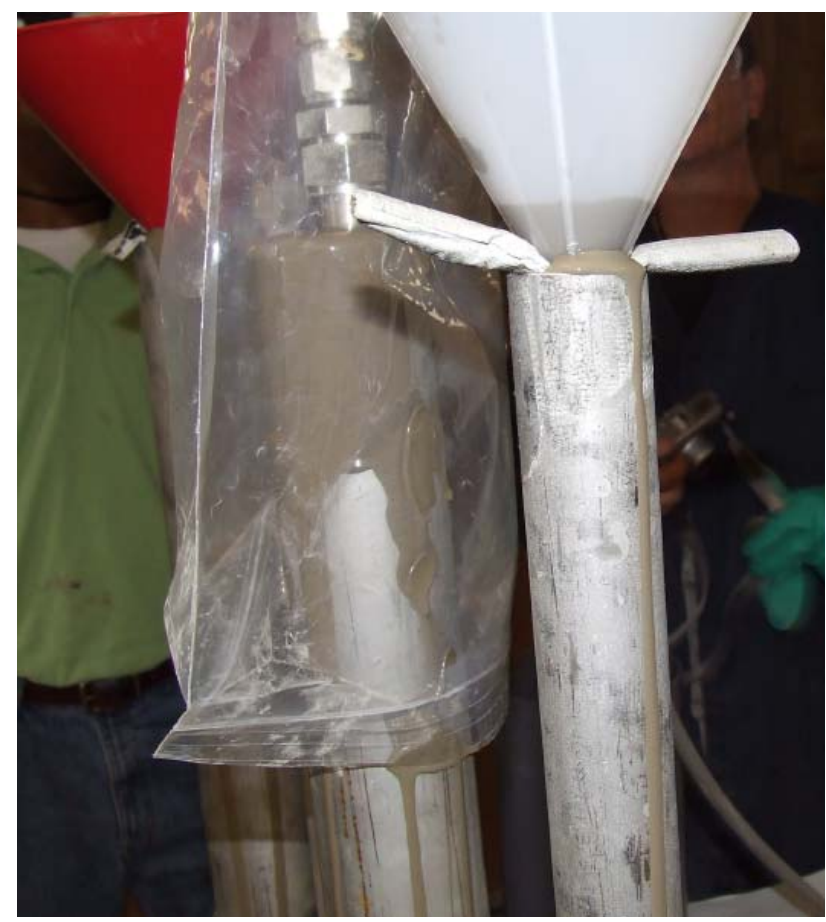

Figure 5-3. Pump filling through tube from bottom up of 2 inch pipe (left) and gravity filling through a funnel of 1 inch pipe (right). 


\subsection{Characterization of Grout Used in Tier 1A Mock Up Tests}

Fresh property characterization of the two grout mixes used in the Tier 1A mock up test are provided in Table 5-3. Set time of mix T1a-62.5FA was determined using the Ultrasonic Pulse Velocity (UPV) Method. See Figure 5-4. Set time of the other mix was not measured. Cured property data for these mixes will be reported as they become available. Current results are provided in Table 5-3.

Table 5-3. Characterization of grouts used in the Tier 1A mock up test.

\begin{tabular}{|c|c|c|}
\hline Property & T1a-62.5FA-C & T1a-75FA-C \\
\hline $\begin{array}{l}\text { ASTM C939 Flow cone (s), } \\
\text { after paddle mixing }\end{array}$ & 23 & 35 \\
\hline $\begin{array}{l}\text { ASTM C939 Flow cone (s), } \\
\text { after paddle mixing and after } \\
\text { shear mixing }\end{array}$ & 16 & 19.1 \\
\hline $\begin{array}{l}\text { Modified ASTM D6103 } \\
\text { Static Spread (in) } \\
\text { after mixing and after static } \\
\text { period (min) }\end{array}$ & $\begin{array}{c}\mathrm{T}_{\mathrm{i}}=16.5 \\
\mathrm{~T}_{30}=12.75 \\
\mathrm{~T}_{60}=10.5 \\
\mathrm{~T}_{90}=\mathrm{NM} \\
\mathrm{T}_{120}=10.5 \\
\mathrm{~T}_{180}=6.5 \\
\mathrm{~T}_{240}=\text { no flow }\end{array}$ & $\begin{aligned} \mathrm{T}_{\mathrm{i}} & =15.5 \\
\mathrm{~T}_{30} & =11.63 \\
\mathrm{~T}_{60} & =8.75 \\
\mathrm{~T}_{90} & =8.63 \\
\mathrm{~T}_{120} & =7.63 \\
\mathrm{~T}_{180} & =\mathrm{NM} \\
\mathrm{T}_{240} & =\mathrm{NM}\end{aligned}$ \\
\hline Grout Temperature $\left({ }^{\circ} \mathrm{F}\right)$ & 72 & 70 \\
\hline Unit Weight (lbs/cft) & 108.5 & 108.1 \\
\hline Air Content (vol.\%) & 2.2 & 2.1 \\
\hline UPV Set Time (hr) & 6 & NM \\
\hline Bleed (ml) & 0 & 0 \\
\hline Strengths (psi) & $\begin{array}{l}1460 @ 7 \text { days } \\
3085 @ 28 \text { days } \\
4180 @ 90 \text { days }\end{array}$ & $\begin{array}{l}850 @ 7 \text { days } \\
2340 @ 28 \text { days } \\
3070 @ 90 \text { days }\end{array}$ \\
\hline $\begin{array}{l}\text { Saturated hydraulic } \\
\text { conductivity, } \mathrm{K}_{\mathrm{hsat} @ 20 \mathrm{C}}(\mathrm{cm} / \mathrm{s}) \\
\text { ASTM D-5804-10, Method C } \\
\text { (URS N-Area) }\end{array}$ & $1.5 \mathrm{E}-09$ & 2.0E-09 \\
\hline
\end{tabular}




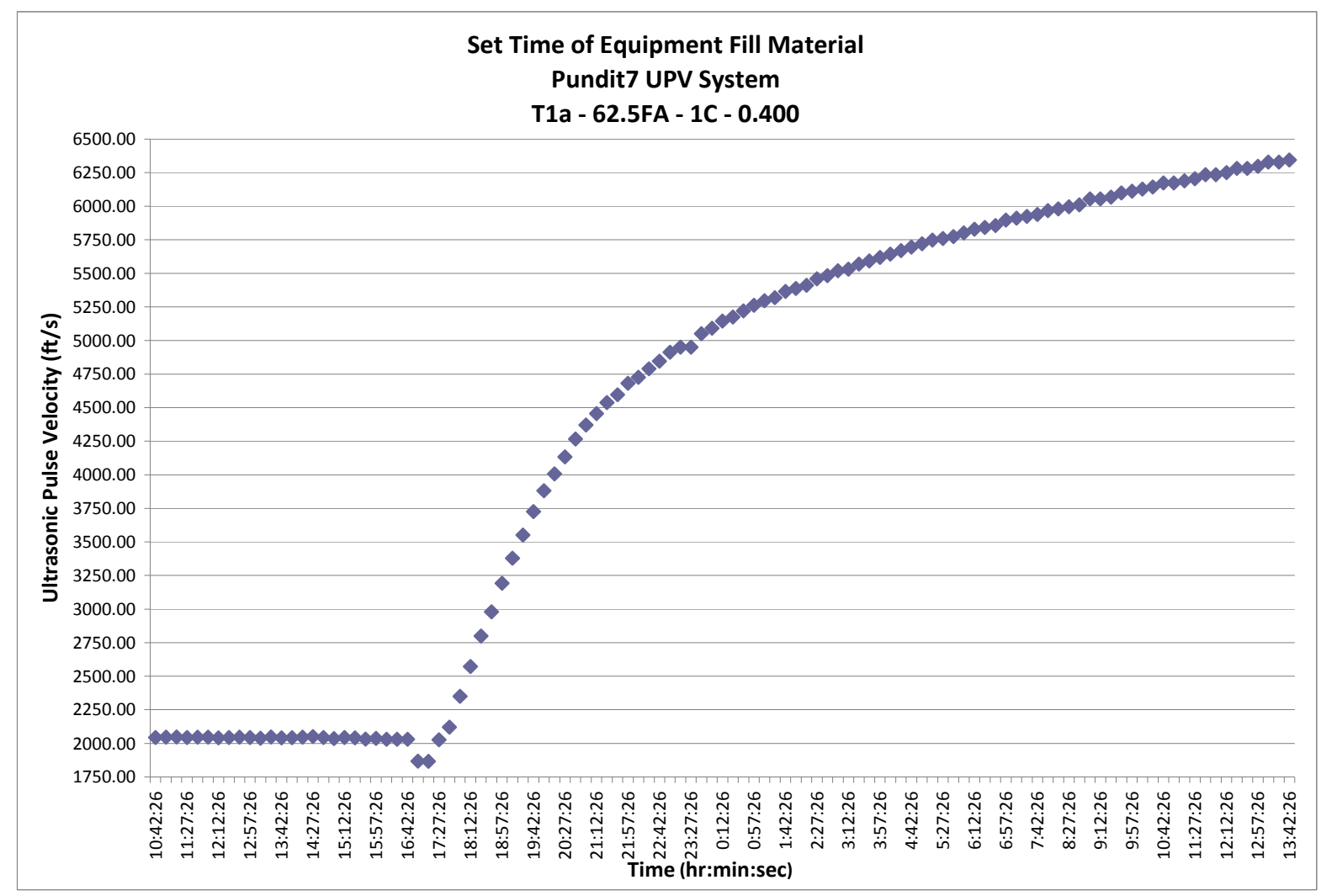

Figure 5-4. Velocity Variation with Time through Grout. 


\subsection{CONCLUSIONS}

- The ADMP is the most difficult piece of vertically positioned ancillary equipment to fill because of its internal configuration and long flow path (55 ft.).

- The Tier 1A mock up test configuration was a simplified representation of the actual ADMP in Tank $18 \mathrm{~F}$ and was intended to the obtain data for establishing the grout rheology requirements for filling the ADMP, i.e., most difficult equipment to fill.

- The Tier 1A mock up test did not utilize full-scale mixing and delivery systems. Consequently, limited testing, data evaluation, and interpretation was performed because full scale processing impacts grout properties and could not be simulated.

- The heat of reaction measured for the SRR cooling coil grout, which was the base case mix for filling ancillary equipment, was too high $(>100 \mathrm{C})$. Consequently, the base case required modification for the equipment fill application. Modification consisted of dilution with a readily available relatively inert material.

- The fly ash adjusted cooling coil mix, T1A-62.5FA, met the ASTM C939 flow cone target value identified for the mock up test, i.e., 16 seconds. This is $2 \mathrm{X}$ the value for water. (Grout requirements are discussed in a separate document [10]. The ingredients in the mix are provided below:

\begin{tabular}{|l|c|c|}
\hline Ingredient & T1a-62.5FA (wt. \%) & T1a-62.5FA (lbs / cu ft) \\
\hline Masterflow $^{\circledR} 816$ & 24.35 & 26.47 \\
\hline Blast Furnace Slag, Grade 100 & 6.50 & 44.11 \\
\hline Fly Ash, Class F, ASTM C618 & 40.59 & 7.06 \\
\hline Domestic Water & 28.57 & 31.07 \\
\hline w/cm & 0.40 & 0.40 \\
\hline
\end{tabular}

- Mix T1A-62.5FA successfully filled the mock up forms (ADMP form and one and two inch ID pipes) in the Tier 1A Test by gravity filling. Based on the Tier 1A test, this mix is suitable for gravity filling the ancillary equipment geometries and pipe geometries down to at least 1 in diameter in Tanks 18-F and 19-F provided that this material can be produced under scaled up field conditions with a $\leq 16$ second ASTM C939 flow rheology. This is assuming that the cured properties meet the assumptions in the FTF Performance Assessment [4]. Under static conditions, Mix T1A-62.5 still flowed at about 2 hours. However the flowability decreased as function of time.

- Under dynamic conditions (stirred) this grout is expected be more flowable after 2 hours than if it were held under static conditions. However flowability under dynamic conditions depends on the energy imparted during stirring, the mass of material, and ambient conditions.

- Cured property data for these modified formulations will be reported as they become available.

- Based on the Tier 1A testing, the recommended fill rate for the ADMP is no more than 4 gallons per minute in order to allow venting and to not overly pressurize the lower chambers. Both of these conditions can stop grout flow and leave voids. 


\subsection{RECOMMENDATIONS}

- The fly ash adjusted cooling coil mix, T1A-62.5FA is recommended for the filling the Tank 18-F and 19-F abandoned equipment provided that the full-scale production process produces grout with the same or improved slurry (fresh) properties.

- Evaluate the rheology of the $62.5 \%$ fly ash modified cooling coil grout mix prepared in the SRR full-scale mixing and pumping equipment to determine whether an ASTM C939 flow cone value of $\leq 16$ seconds can be achieved.

- Examine cross-sections of the Tier 1A mock up pipes that were filled during testing for voids and/or shrinkage cracks.

- Address the possibility of displaced liquid that may be contained in ancillary equipment that is being filled in the Grout Placement Strategy, e.g., identify detection methods to prevent over filling equipment during grouting. Consider using a two step filling process. The specific gravity of the grout will be higher then residuals left inside equipment and ancillary components. A two step fill process is suggested with a delay between steps for material to solidify.

- Screen the grout to remove clumps and foreign objects to eliminate plugging. A screen with openings $\leq 3 / 8$ inch should be installed at the points of placement, i.e., before grout is discharged into the funnel / hopper at the top of the ADMP and other equipment.

- If SRR decides to perform additional mock up testing, monitor pressures inside mock up form and incorporate lessons learned in the grout placement strategy.

- Consider collecting pressure and grout flow data from the actual production equipment and grout distribution lines if operational readiness tests are performed. Pressure data should be collected at the pump and near the outlet point to ensure lines are properly sized for flow rates.

- If pipes are filled using tubes inserted to the bottom of the pipes, consider placing slots at strategic locations along the elevation of tubes inserted in pipes during grout filling if SRR identifies this as the preferred grout placement strategy for filling in the implementation plan. This will mitigate the chance of backfilling the tube with residual contaminates if there is an elevation difference between the connection point at the tank top and grout pump. This will also make pumping easier as the grout fill level inside the component increases (i.e., will not be pumping against a changing head).

- Revisit the Engineering and PA requirements for grouting the chromate cooling coils and ancillary systems. The opportunity to reduce cost by adding inert filler to the cooling coil grout recipe may exist for Tanks 5-F and 6-F or other SRS Type I and II liquid waste tanks. 


\subsection{REFERENCES}

1. SRR Closure and Waste Disposal Authority, 2011. "Industrial Wastewater Closure Module for the Liquid Waste Tanks 18 and 19 F-Area Tank Farm, Savannah River Site," SRRCWDA-2010-00003, Revision 0, August 2011, Industrial Waste Water Construction Permit No. 17,424-IW, Savannah River Remediation LLC, Savannah River Site, Aiken, SC, 29808.

2. Chandler, V. A., 2011. "Grout Strategy for Tanks 18 and 19 Closure," March 9, 2011, SRRWE-20101-00318, Savannah River Remediations, LLC, Savannah River Site, Aiken, SC, 29808.

3. Hyche, J. P., 2011. "Tier 1A Equipment Grout Mock Up Test Plan,” August 9, 2011, MTPL-F-00011, Savannah River Remediations, LLC, Savannah River Site, Aiken, SC, 29808.

4. Chandler, V. A., 2011. "Technical Task Request: Develop Tank Closure Technology Grout Formulations for Tanks(s) 18 \& 19," HLE-TTR-2011-008, March 10, 2011, Savannah River Remediation, LLC, Savannah River Site, Aiken, SC, 29808.

5. Stefanko, D. B., Guerrero, H. N., Reigel, M. M., and C. A. Langton, 2011. "Task Technical and Quality Assurance Plan for Developing and Testing Grout Formulations for Filling Tanks 18-F and 19-F and Abandoned Equipment," SRNL-RP-2011-00587, Revision 0, March 22, 2011, Savannah River National Laboratory, Savannah River Site, Aiken, SC, 29808.

6. Harbour, J. R., Williams, V. J., Hansen, E. K., and W. L. Mhyre, 2008. "Closure of HLW Tanks - Formulation for Cooling Coil Grout,” WSRC-STI-2008-00172, Rev. 0, April 2008, Savannah River National Laboratory, Savannah River Site, Aiken, SC, 29808.

7. Hansen, E. K., Cozzi, A. D., 2008. "Closure of HLW Tanks - Phase 2 Full Scale Cooling Coils Grout Fill Demonstrations," WSRC-STI-2008-00298, Revision 0, June 2008, Savannah River National Laboratory, Savannah River Site, Aiken, SC, 29808.

8. Carter, M., 2011. “Tanks 18 and 19 Internal Equipment Volumes," SRR-LWE-2011-00150, Revision 0, August 11, 2011, Savannah River Remediations LLC, Savannah River Site, Aiken, SC 29808.

9. Rosenberger, K. H., 2011. Personal communication with SRR and SRNL Tank 18 and 19-F Closure Team, Savannah River Remediations LLC, Savannah River Site, Aiken, SC 29808.

10. Stefanko, D. B. and C. A. Langton, 2011. "Tank 18 and 19-F Equipment Grout Fill Material Evaluation and Recommendations," SRNL-STI-2011-00592, Revision 0, November 2011, Savannah River National Laboratory, Savannah River Site, Aiken, SC, 29808.

11. Vendor Print File for ADMP, 2002. VPF 22731. Savannah River Site Central Shops Document Control, Savannah River Site, Aiken, SC, 29808.

12. Leishear, R. A., 2002. Modification to ADMP Design, Task \#5, SOW-PR4E8418, Revision 0, Westinghouse Savannah River Company, Savannah River Site, Aiken, SC 29808.

13. URS, 2009. 717-5N EEC, EEC-ARRA-N-2009-019, URS Washington Division Quality and Testing Group, Savannah River Site, Aiken, SC 29808. 
SRNL-STI-2011-00564

Revision 0

\section{APPENDIX A - ADMP INTERNAL FLOW PATH}

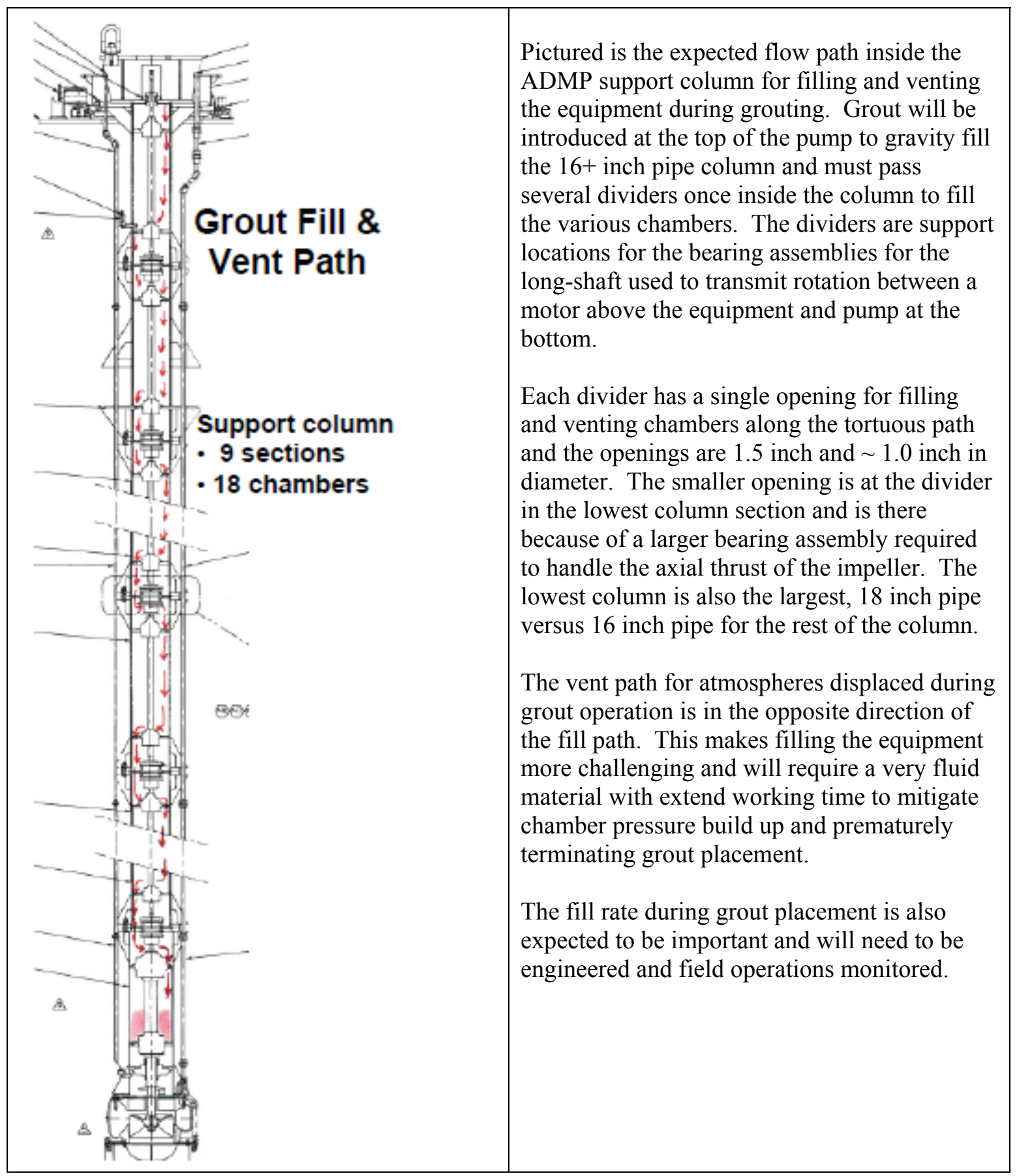

Figure A-1. ADMP internal flow paths. 
SRNL-STI-2011-00564

Revision 0

\section{APPENDIX B - ADMP EXTERNAL COLUMN PIPING}

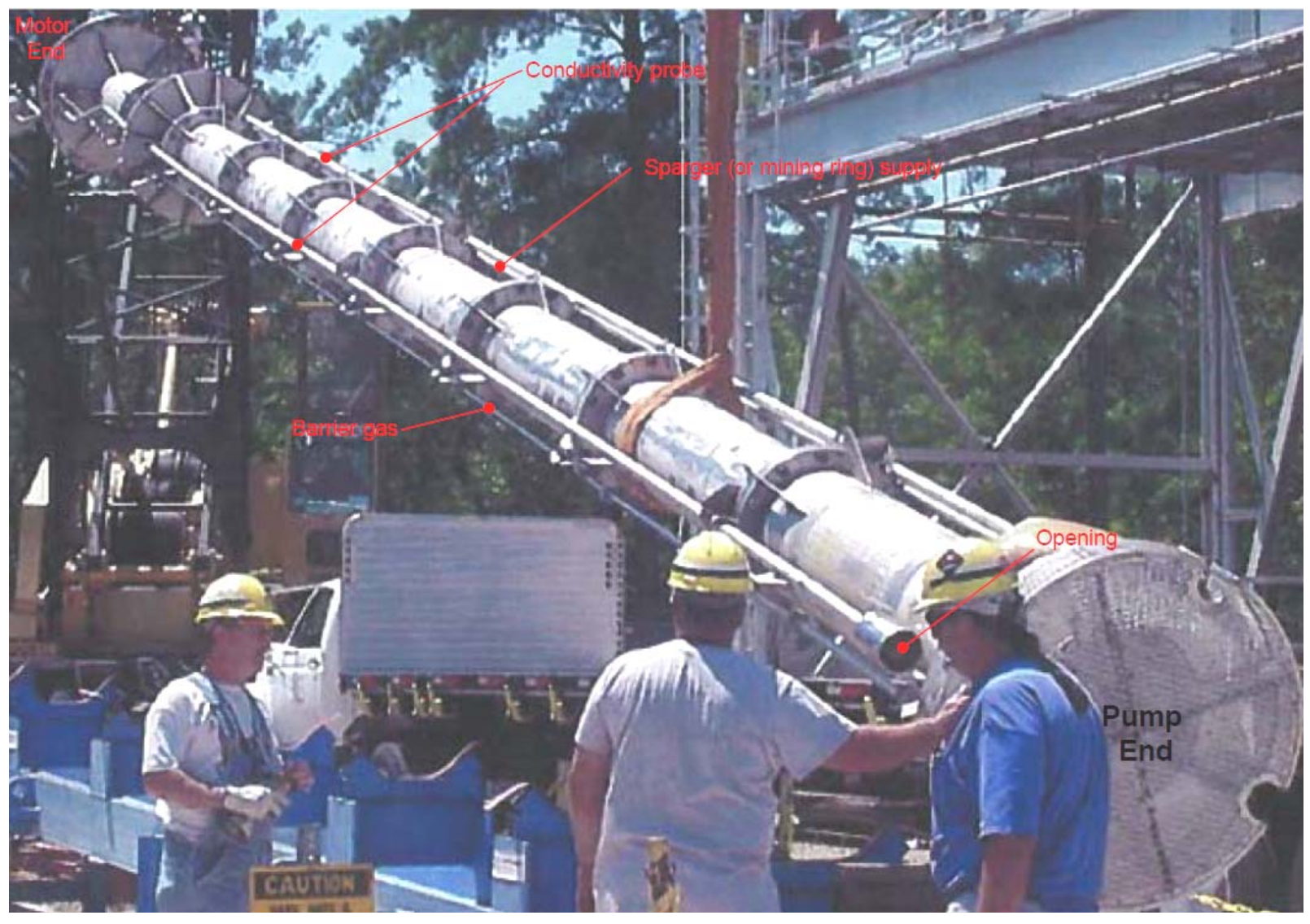

Figure B-1. ADMP with attached external piping. 
APPENDIX C - Approximate Internal Volumes of Equipment Left in Tanks 18-F and 19-F FROM SRR-LWE-2011-00150 Revision 0 [8]

Table C-1. Tank 18-F Ancillary Equipment Estimated Internal Volumes.

\begin{tabular}{|c|c|c|c|c|c|c|c|}
\hline \multicolumn{8}{|l|}{ Tank 18} \\
\hline Equipment & Riser & $\begin{array}{c}\text { Diameter } \\
\text { (ft) }\end{array}$ & $\begin{array}{c}\text { Height } \\
\text { (ft) }\end{array}$ & $\begin{array}{c}\text { Area } \\
(\mathrm{sq} . \mathrm{ft})\end{array}$ & $\begin{array}{l}\text { Volume } \\
\text { (cu. ft) }\end{array}$ & $\begin{array}{l}\text { Volume } \\
\text { (cu. yds) }\end{array}$ & $\begin{array}{l}\text { Volume } \\
\text { (Gallons) }\end{array}$ \\
\hline *ADMP & Center & *See Note & $*$ & $*$ & 90 & 3.33 & 673.2 \\
\hline $\begin{array}{l}\text { Telescoping Transfer } \\
\text { Pump (TTP) }\end{array}$ & West & 0.896 & 45 & 0.63 & 28.4 & 1.1 & 212.2 \\
\hline \multirow[t]{2}{*}{ *Slurry Pumps(2) } & East & 1.33 & 39.4 & 1.4 & 55.0 & 2.0 & 411.5 \\
\hline & Northwest & 1.33 & 39.4 & $\overline{1.4}$ & 55.0 & 2.0 & 411.5 \\
\hline $\begin{array}{l}\text { Evaporator Feed Pump } \\
\text { (2" Dia. Piping) }\end{array}$ & Southeast & 0.17 & 3.5 & 0.022 & 0.08 & 0.003 & 0.6 \\
\hline $\begin{array}{l}\text { Evaporator Feed Pump } \\
\text { (1.5" Dia. Piping) }\end{array}$ & Southeast & 0.125 & 3.5 & 0.012 & 0.04 & 0.002 & 0.3 \\
\hline $\begin{array}{l}\text { Evaporator Feed Pump } \\
\text { (3/4" Dia. Piping) }\end{array}$ & Southeast & 0.0625 & 2.6 & 0.003 & 0.01 & 0.0003 & 0.1 \\
\hline $\begin{array}{l}\text { Evaporator Feed Pump } \\
\text { (2.5" Dia. Piping) }\end{array}$ & Southeast & 0.21 & 20 & 0.034 & 0.68 & 0.03 & 5.1 \\
\hline Piping (1" Dia. piping) & Northeast & 0.083 & 39 & 0.005 & 0.21 & 0.01 & 1.6 \\
\hline $\begin{array}{l}\text { Piping (1.5" Dia. } \\
\text { piping) }\end{array}$ & Northeast & 0.125 & 39 & 0.012 & 0.48 & 0.02 & 3.6 \\
\hline Total & & & & & 229.8 & 8.51 & 1719.7 \\
\hline
\end{tabular}

*Note: ADMP and slurry pump equipment volumes also referenced within WSRC-SA-200200007 [11]

Table C-2. Tank 19-F Ancillary Equipment Estimated Internal Volumes.

\begin{tabular}{|l|l|r|r|r|r|r|r|}
\hline Tank 19 & \multicolumn{1}{|c|}{ Riser } & $\begin{array}{c}\text { Diameter } \\
\text { (ft) }\end{array}$ & $\begin{array}{c}\text { Height } \\
\text { (ft) }\end{array}$ & $\begin{array}{c}\text { Area } \\
\text { (sq. ft) }\end{array}$ & $\begin{array}{r}\text { Volume } \\
\text { (cu. ft) }\end{array}$ & $\begin{array}{c}\text { Volume } \\
\text { (cu. yds) }\end{array}$ & $\begin{array}{c}\text { Volume } \\
\text { (Gallons) }\end{array}$ \\
\hline $\begin{array}{l}\text { Telescoping } \\
\text { Transfer Jet (TTJ) } \\
\text { (Discharge line) }\end{array}$ & Northwest & 0.256 & 23.42 & 0.05 & 1.2 & 0.045 & 9.0 \\
\hline Supply line & Northwest & 0.172 & 23.25 & 0.02 & 0.5 & 0.020 & 4.1 \\
\hline Thermowell & Northeast & 0.087 & 39 & 0.01 & 0.2 & 0.009 & 1.8 \\
\hline $\begin{array}{l}\text { Dip Tube } \\
\text { Assembly (Level } \\
\text { Instrumentation) } \\
\text { (3/4" Dia. Piping) }\end{array}$ & Northwest & 0.07 & 43.3 & 0.004 & 0.16 & 0.006 & 1.2 \\
\hline $\begin{array}{l}\text { Dip Tube } \\
\text { Assembly } \\
\text { (3/4" Dia. Piping) }\end{array}$ & Northwest & 0.07 & 42.5 & 0.004 & 0.16 & 0.006 & 1.2 \\
\hline Total & & & & & $\mathbf{2 . 3}$ & $\mathbf{0 . 0 8 5}$ & $\mathbf{1 7 . 2}$ \\
\hline
\end{tabular}


SRNL-STI-2011-00564

Revision 0

Page 26 


\section{Distribution:}
A. B. Barnes, 999-W
H. H. Burns, 773-43A - Rm.227
B. T. Butcher, 773-43A - Rm.212
V. A. Chander, 704-70F
L. B. Collard, 773-43A - Rm.207
D. A. Crowley, 773-43A - Rm.216
S. D. Fink, 773-A
B. J. Giddings, 786-5A
M. E. Harrel, 241-108F
J. E. Herbert, 241-108F
C. C. Herman, 999-W
J. P. Hyche, 704-70F
R. C. Jolly, 241-109F
C. A. Langton, 773-43A
S. L. Marra, 773-A
W. L. Mhyre, $717-5 \mathrm{~N}$
B. A. Martin, 705-1C
A. M. Murray, 773-A
M. E. Pallon, 717-11F
F. M. Pennebaker, 773-42A
W. Pope Jr., 717-5N
K. H. Rosenberger, 705-1C
J. W. Rush, 241-108F
J. H. Scogin, 773-A
A. J. Tisler, 704-26F
J. T. Waymer, $717-5 \mathrm{~N}$
W. R. Wilmarth, 773-A
D. C. Wood, 704-26F

(1 file copy \& 1 electronic copy), 773-43A -

Rm.213 